Historic, archived document

Do not assume content reflects current scientific knowledge, policies, or practices. 



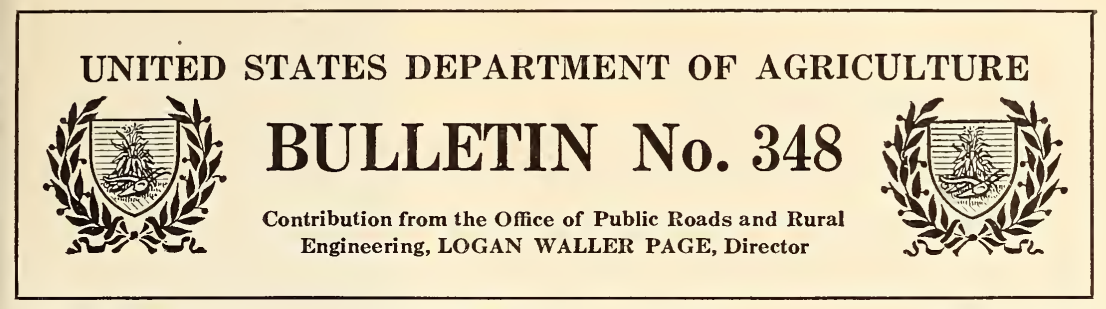

Washington, D. C.

PROFESSIONAL PAPER

April 4, 1916

\section{RELATION OF MINERAL COMPOSITION AND ROCK STRUCTURE TO THE PHYSICAL PROPERTIES OF ROAD MATERIALS.}

By E. C. E. Lord, Petrographer.

\section{CONTENTS.}

Introduction ............................

Examination and clıssiication of rocks for

road making...........................

Mineral composition of rocks for road mak-

ing..................................

Physical properties of road materials.........

Page.

1 General relation between the physical properties of rocks and their mineral composition and structure..................... Effect of secondary minerals on the physical properties of rocks for road building........

summary and conclusion..................
Page.

\section{INTRODUCTION.}

The importance of selecting proper materials for the construction of macadam roads has become generally recognized and has led to a careful study in this office of a large number of rocks in order to properly determine their mineral composition and road-making properties. The earlier results of these investigations, which were published in $1911,{ }^{1}$ have demonstrated that certain physical properties are in a general way characteristic of definite rock types and may be attributed to the peculiar arrangement and composition of the rockforming constituents. With a largely increased number of samples available for examination it has been found possible to correlate these relations more exactly, and in the present publication the results obtained will be presented with special reference to the effect of secondary minerals on the physical properties of rocks for road building.

In considering these results it should be noted that owing to the complexity of the subject and of the possible effect of many variables, it has not been possible to develop definite laws. The discussion of the effect of secondary minerals has therefore been based necessarily

1 Examination and Classification of Rocks for Road Building, U. S. Office of Public Roads Bul. 37. 17715ํ-Bull. $348-16-1$ 
upon their tendency to influence the physical characteristics of the rocks in which they occur.

It will be found desirable to outline, in advance, the method employed by this office in the analysis and classification of road materials, as well as to review briefly the mineral composition of rocks and the manner in which their more important physical properties have been determined.

\section{EXAMINATION AND CLASSIFICATION OF ROCKS FOR ROAD MAKING.}

Upon receipt of the rock sample, which, according to printed instructions, should weigh not less than 30 pounds and be collected with care to represent as nearly as possible an average of the whole rock outcrop, it is examined in a general way to determine the proper method of analysis.

Both rocks consisting chiefly of the carbonate minerals (limestone and dolomite) as well as unconsolidated deposits (clay, gravel, sand) are subject to chemical or mechanical analysis when necessary, whereas all other materials are examined microscopically to determine the quantitative proportions of the minerals present in the rock sample. To carry out a quantitative analysis of this kind it is necessary to prepare a thin section of the sample so that its mineral

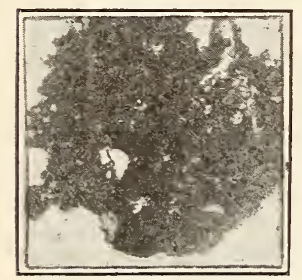

FIG. 1.-Thin section of rock mounted on glass. constituents may be readily recognized and measured. Figure 1 represents such a section of rock mounted in Canada balsam.

The section is prepared by grinding down with emery powder on a revolving iron disk a representative chip from a hand sample of the rock until a smooth, flat surface is obtained. The chip is then firmly attached to a thick glass plate of appropriate size by means of Canada balsam, with the prepared flat surface against the glass, and the grinding continued on the opposite surface until the section approaches the thickness of tissue paper and becomes transparent, when it is transferred to an object glass and attached by means of the balsam, and finally covered with a very thin cover glass. The minerals present in the slide are then identified under the microscope and their relative proportions determined by means of a measuring apparatus devised by L. W. Page. This consists of an ordinary fixed eyepiece having a square field of about 1 centimeter area divided into 100 equal parts, as shown in figure 2.

With the aid of this crossline micrometer, each square of which is 1 one-hundredth or 1 per cent of the whole field, the relative proportions, expressed in percentage, of the minerals occupying the field can be readily determined by simply noting the number of squares covered by each mineral in turn. The average results of 20 such 
road making.

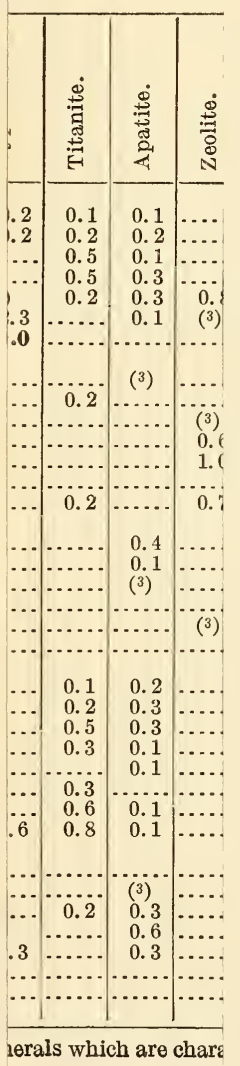





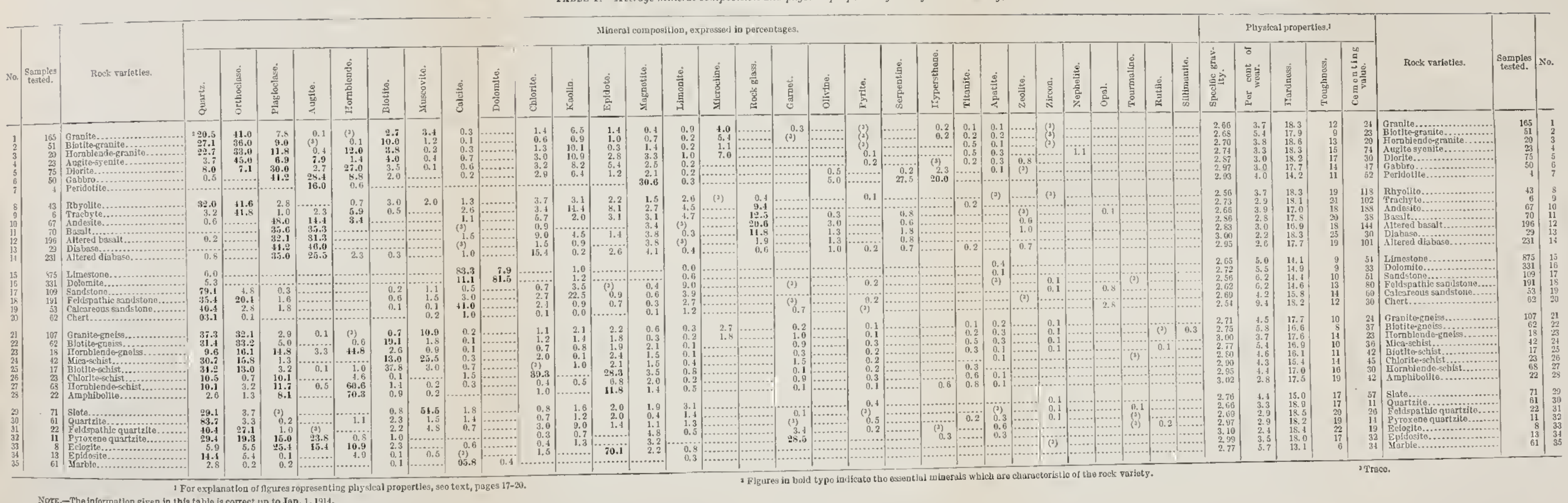



measurements taken in various parts of the section will, under ordinary conditions, give the volumetric proportions of the minerals in the rock itself. If desired, the chemical composition of the rock may be approximately obtained by multiplying the volumetric percentages of all the minerals present by their specific gravities and reducing the whole to a basis of 100 , and then nultiplying the values obtained by the percentages of the chemical components, reckoned as oxides, belonging to each mineral. ${ }^{1}$

The average mineral composition and physical properties of all rock samples analyzed and tested in this office up to January 1, 1914, are given in Table 1.

The material has been arranged in groups following the general classification adopted by this office, which is as follows:

TABLE 2.-General classification of rocks.

\begin{tabular}{|c|c|c|}
\hline Class. & Туре. & Family. \\
\hline II. Sedimentary... & 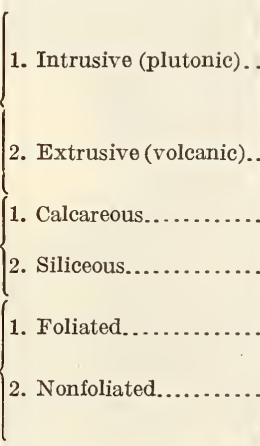 & $\begin{array}{l}\text { a. Granite. } \\
\text { b. Syenite. } \\
\text { c. Diorite. } \\
\text { d. Gabbro. } \\
\text { e. Peridotite. } \\
\text { a. Rhyolite. } \\
\text { b. Trachyte. } \\
\text { c. Andesite. } \\
\text { d. Basalt and diabase. } \\
\text { \{. Limestone. } \\
\text { b. Dolomite. } \\
\left\{\begin{array}{l}\text { a. Shale. } \\
\text { b. Sandstone. } \\
\text { c. Chert (flint). }\end{array}\right. \\
\text { a. Gneiss. } \\
\text { b. Schist. } \\
\text { c. Amphibolite. } \\
\text { a. Slate. } \\
\text { b. Quartzite. } \\
\text { c. Eclogite. } \\
\text { d. Marble. }\end{array}$ \\
\hline
\end{tabular}

Referring to Table No. 1, Nos. 1 to 7 embrace plutonic igneous rocks; 8 to 14, volcanic igneous rocks; 15 to 20, sedimentary rocks; and 21 to 35 , metamorphic rocks or crystalline schists. The average percentages of essential minerals characterizing each rock variety are printed in bold type and the minerals themselves placed in the table approximately in the order of their importance as rock-forming constituents. ${ }^{2} \quad$ The relative value of these various rock types from a road-making standpoint may be best understood after a brief discussion of their mode of origin and mineral characteristics. Under igneous rocks (Nos. 1 to 14) are included all varieties of road material that have solidified from a state of liquid fusion, the structure or manner of mineral aggregation being influenced largely by the rate of cooling of the fused rock magma. Thus, intrusive or plutonic

\footnotetext{
1 Bulletin 37, Office of Public Roads, pp. 10-11.

2 The mineral composition of limestone, dolomite, and marble has been obtained from chemical analyses of about 100 samples.
} 
rocks (Nos. 1 to 7), such as granite, diorite, gabbro, etc. (Pls. I, fig. 1; II, figs. 1, 2), having cooled slowly at great depths below the earth's surface, usually possess large and well-dereloped mineral components, whereas extrusire or rolcanic rarieties (Nos. 8 to 14), cooling more rapidly upon the earth's surface, are finer grained and frequently show so-called porphyritic structures owing to the development of larger crystals in a dense, fine-grained ground mass. (Pls. I, fig. 2; III, figs. 1,2 .)

Sedimentary rocks (Nos. 15 to 20), on the other hand, are made up of mineral or shell fragments that hare been transported mainly by water and deposited in sea or lake depressions in more or less parallel layers and subsequently cemented together through pressure

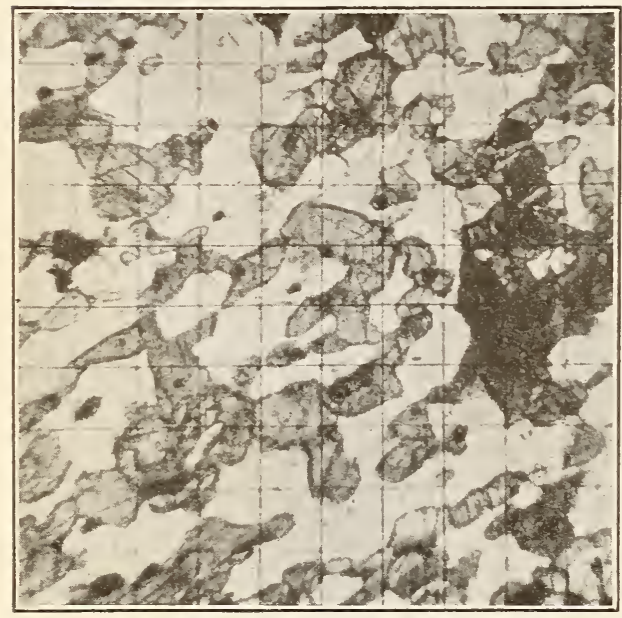

FrG. 2.-Cross-line field illustrating method of estimating minerals in thin section. and the formation of secondary mineral compounds. (Pls. IT, fig. 1; T, fig. 2). Rocks of this class are usually distinctly bedded or stratified. Metamorphic rocks occupy in a measure an intermediate position between those of igneous and sedimentary origin, and are either foliated or schistose (Nos, 21 to 28) through the parallel arrangement of their mineral constituents (Pl.VI), or massire and nonfoliated (Nos. 29 to 35) like marble and quartzite (Pl. V, fig. 1). These structures have been induced by long-continued shearing and compressire forces acting alike on igneous and sedimentary rocks, thereby changing to a greater or less degree the composition and structure of the original rock masses.

\section{MINERAL COMPOSITION OF ROCKS FOR ROAD MAKING.}

Although the road materials tested in this office hare been separated into 35 distinct rarieties, yet it will be seen that but 12 minerals enter prominently into their composition. Some idea of the general appearance of these minerals when perfectly dereloped may be obtained from the photographs reproduced on Plate VII, yet the fact should be borne in mind that when present as rock-forming aggregates these regular crystal shapes are considerably modified and the minerals appear in more or less irregular forms depending upon the character of the rock in which they occur. (Pls. I-III.) 


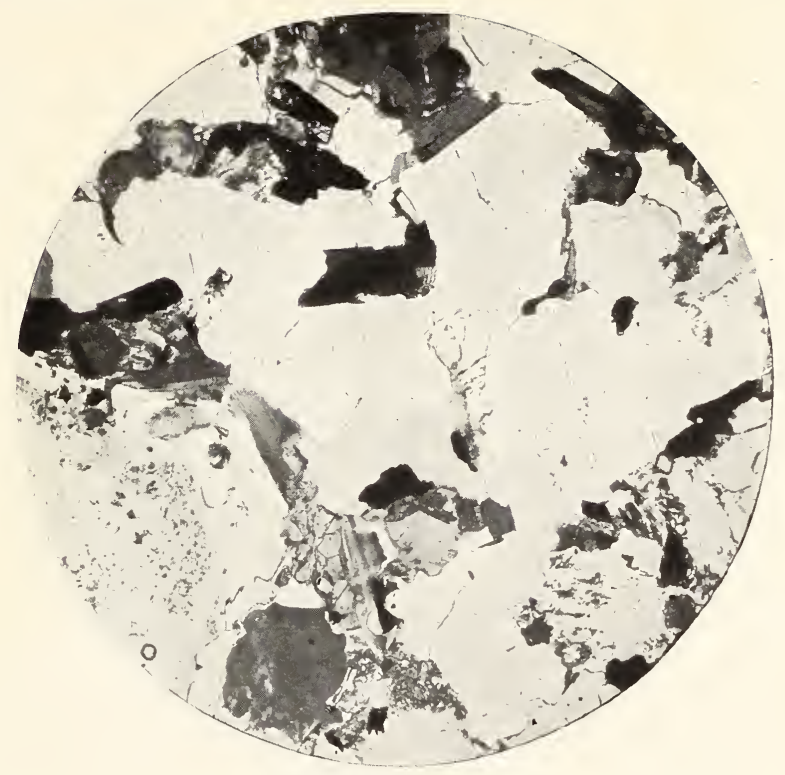

FIG 1.-GRANITE.

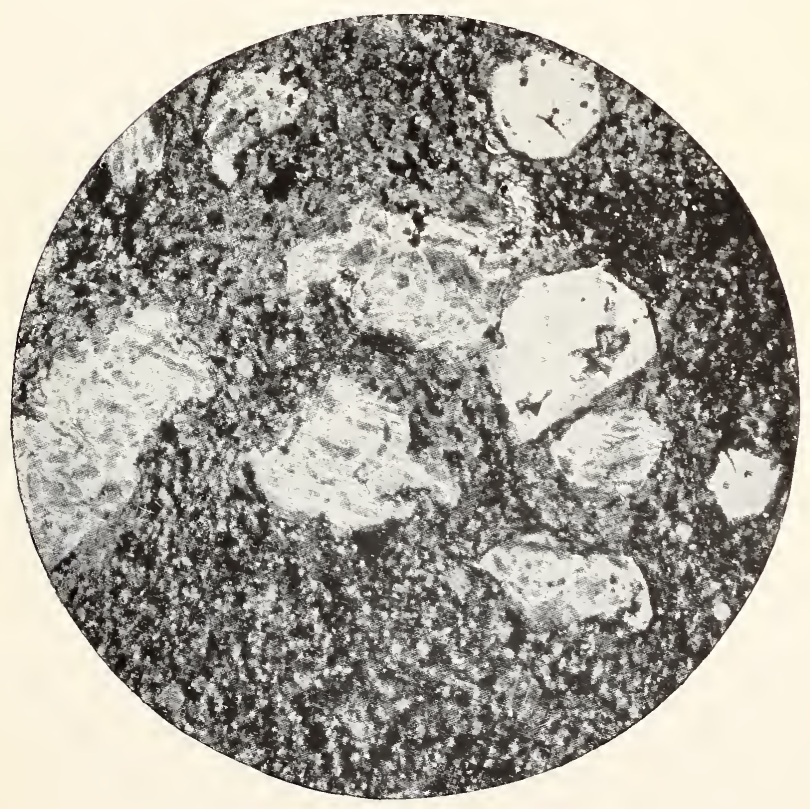

F!G. 2.-RHYOLITE.

IGNEOUS ROCKS. 


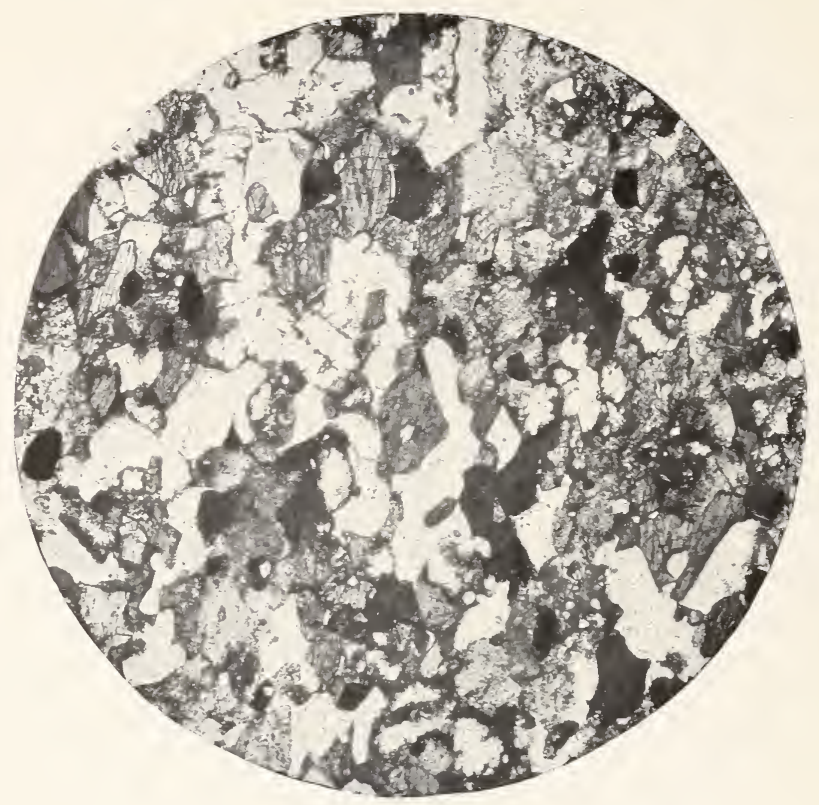

FIG. 1,-DIORITE.

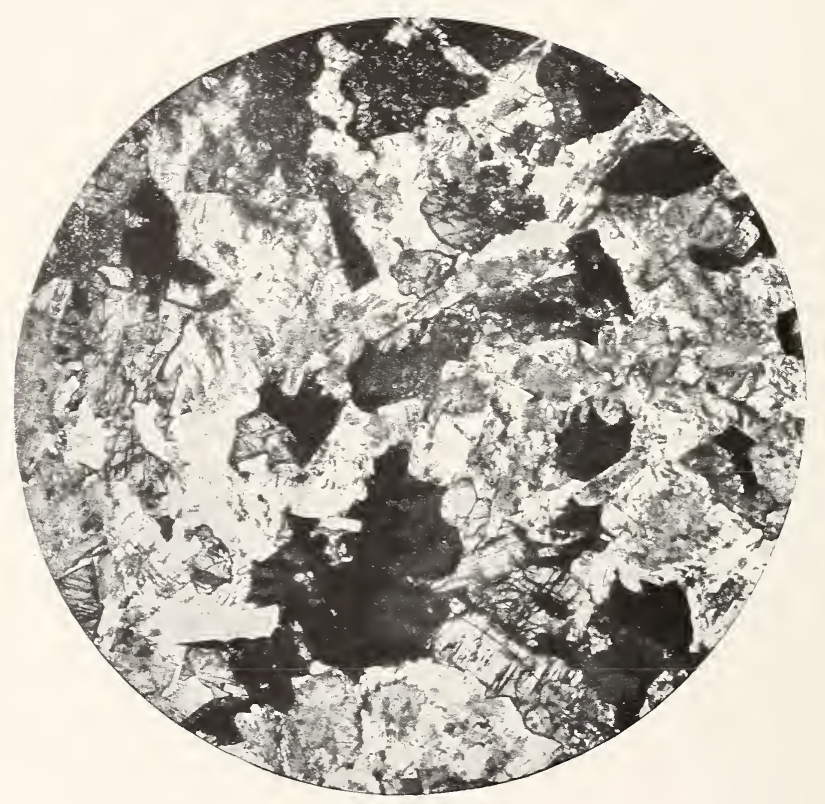

FIG. 2.-GABBRO.

IGNEOUS ROCKS. 


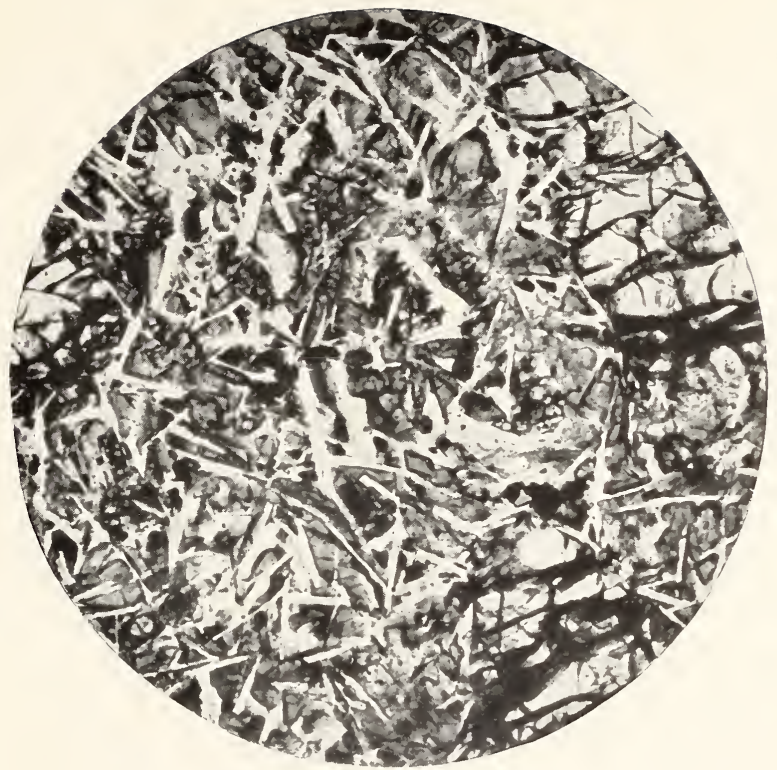

Fig. 1.-BAsalt (Trap).

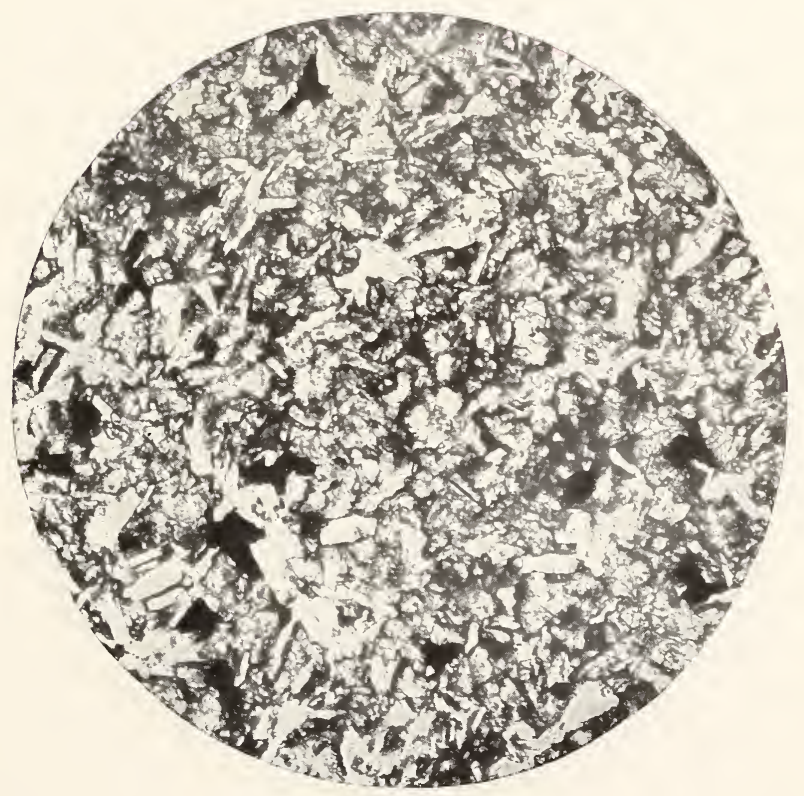

Fig. 2.-DiABASE (TRAP).

IGNEOUS ROCKS. 


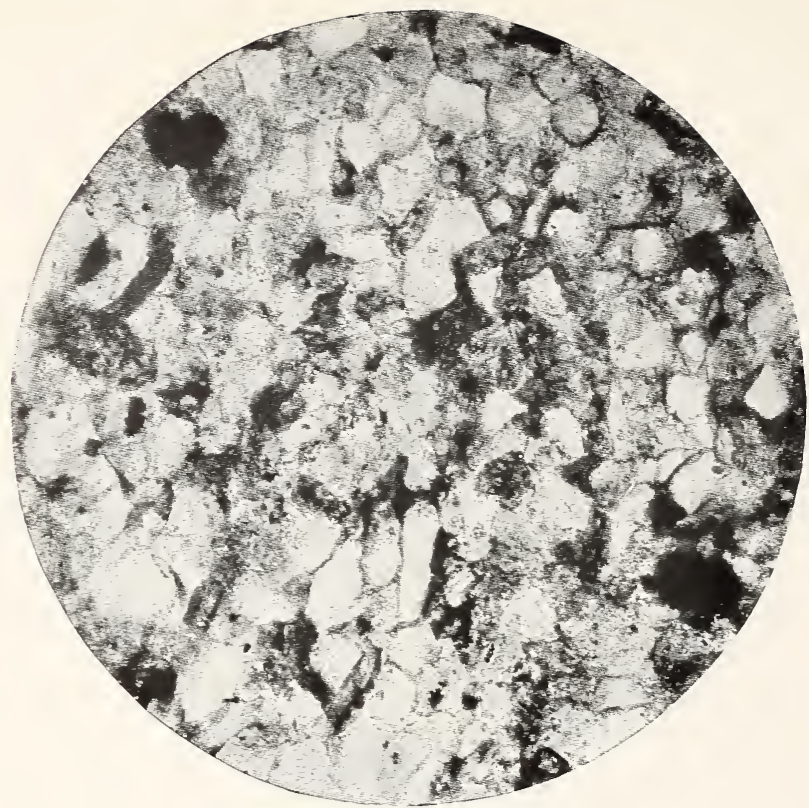

FIG. 1.-SANDSTONE.

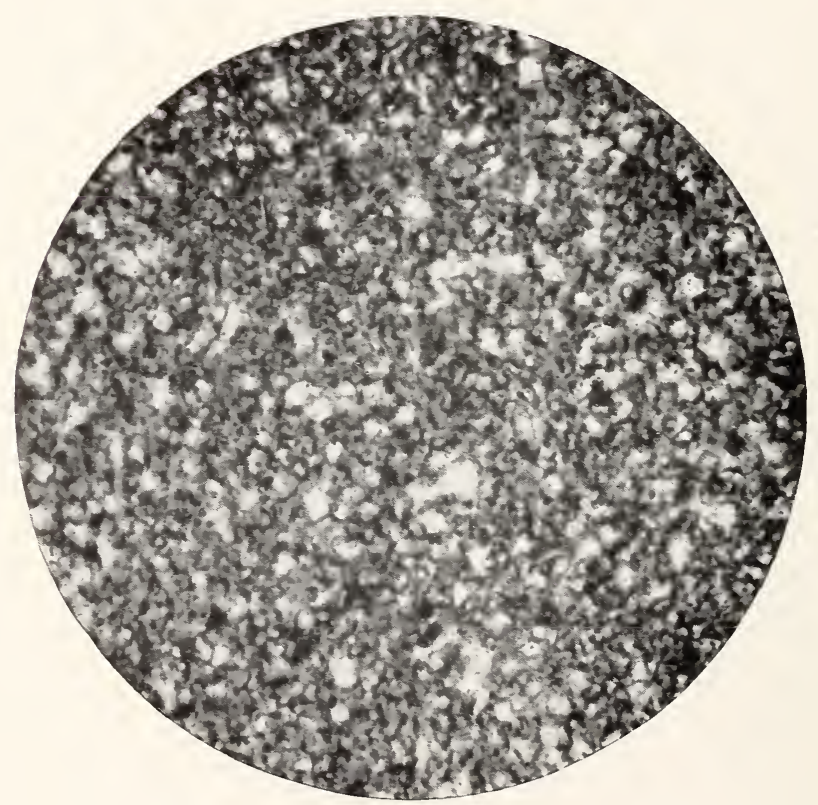

FIG. 2.-CHERT.

SEDIMENTARY ROCKS. 


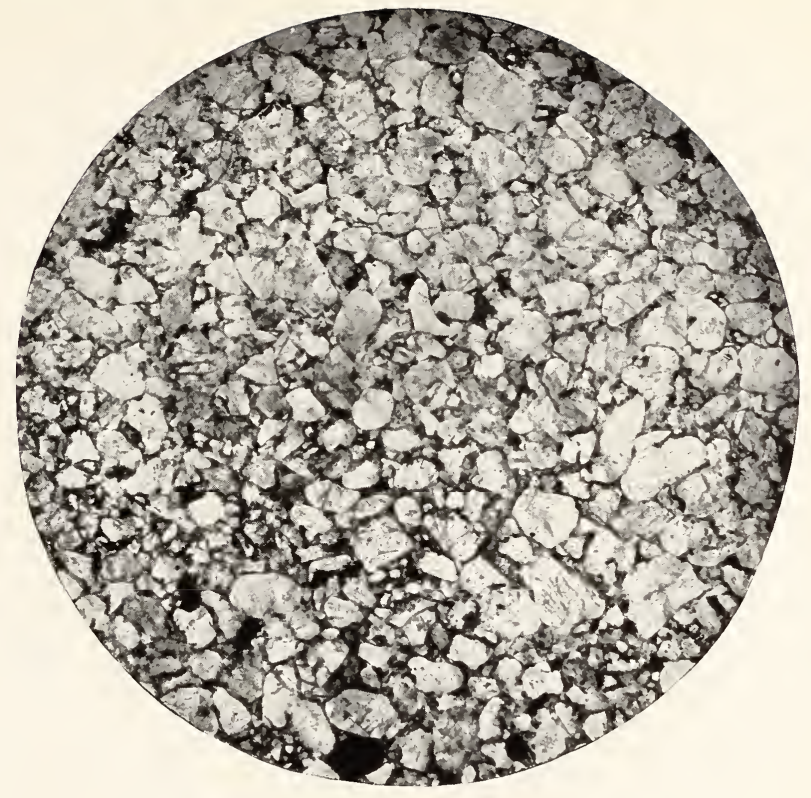

Fig. 1.-QUARTZITE.

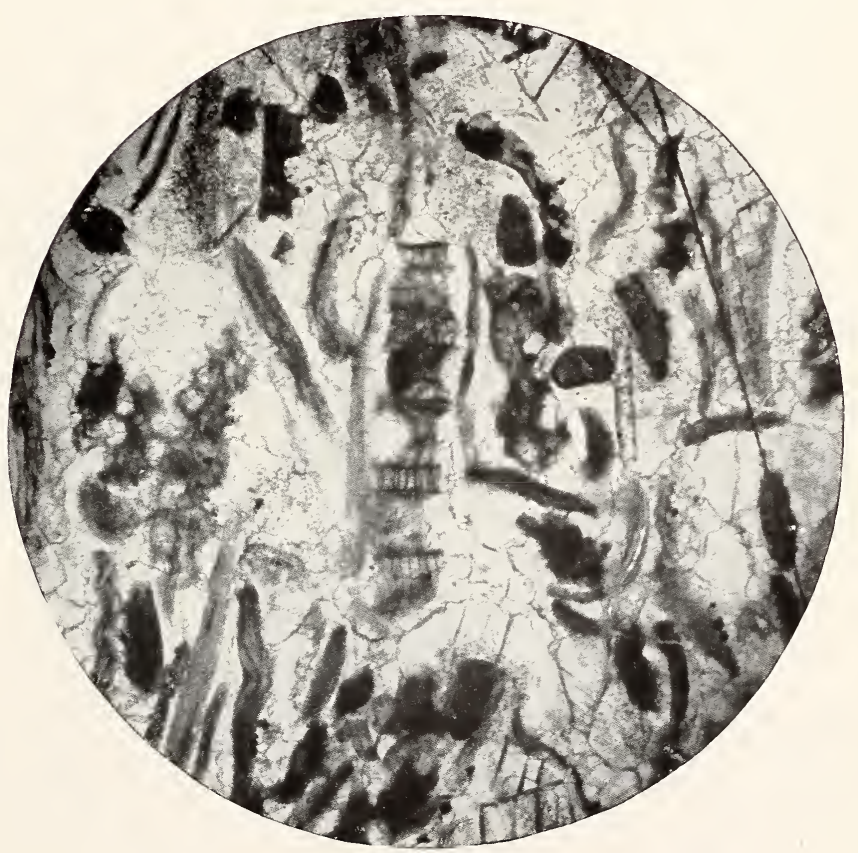

Fig. 2.-FossilifEROUS LIMESTONE.

SEDIMENTARY AND METAMORPHIC ROCKS. 


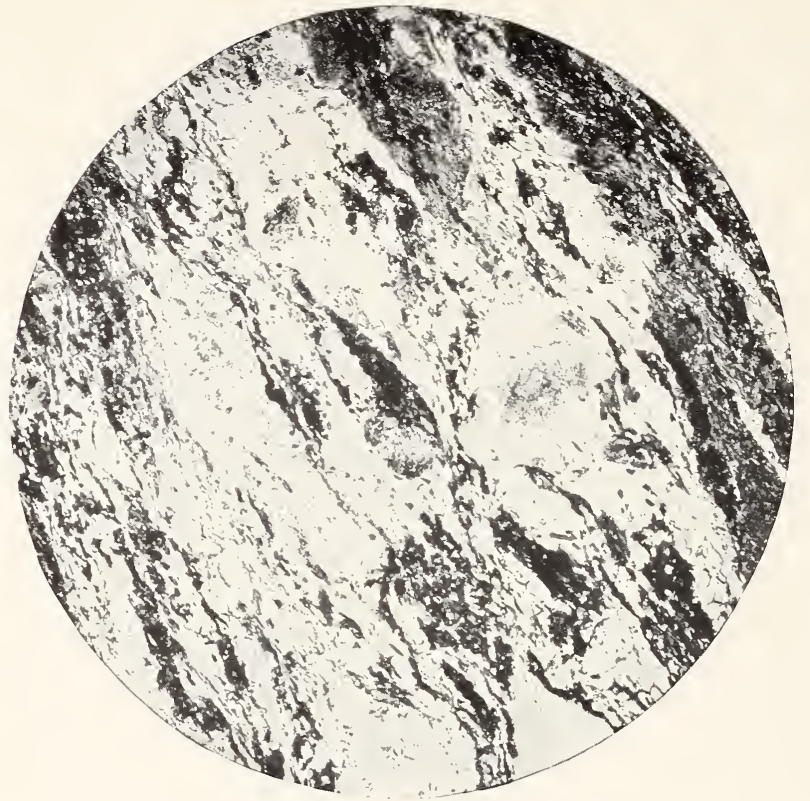

Fig. 1.-GRanite-Gneiss.

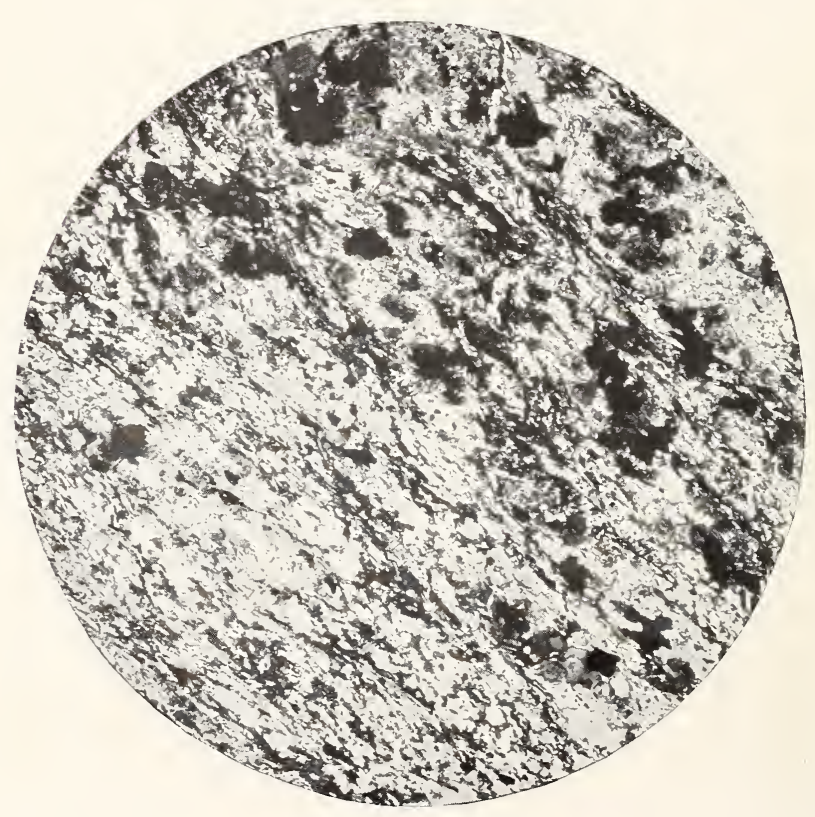

FIG. 2.-MICA-SCHIST.

METAMORPHIC ROCKS. 
Bul. 343, U. S. Dept. of Agriculture.

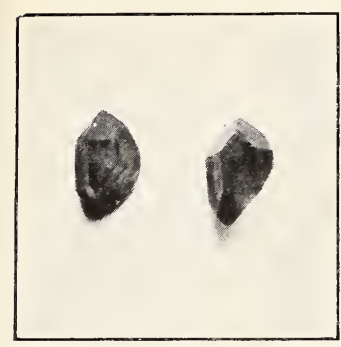

FIG. 1.-QUARTZ.

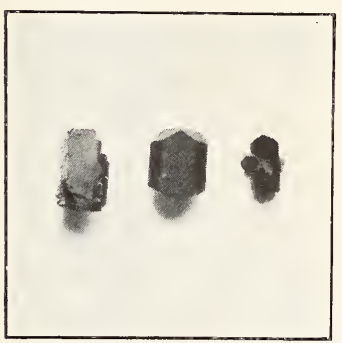

FIG. 4.-AugITE.

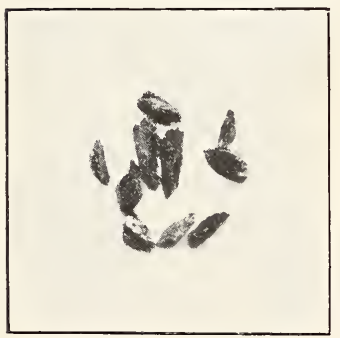

FIG. 7.-CHLORITE.

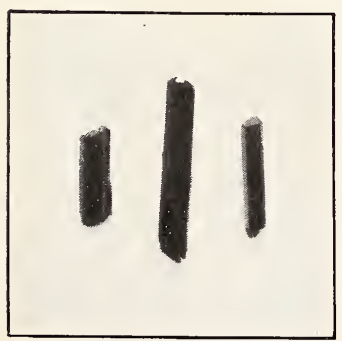

FIG. 10.-EPIDOTE.

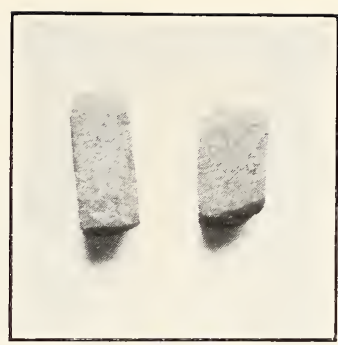

FIG. 2.-ORTHOCLASE.

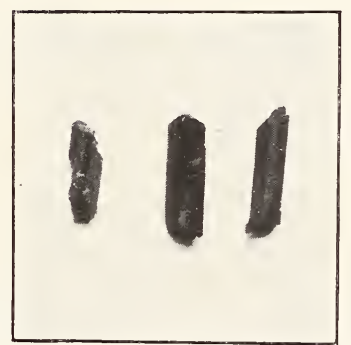

FIG. 5.-HORNBLENDE.

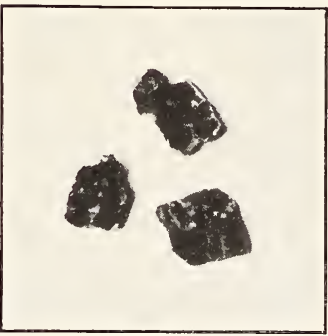

FIG. 8.-BIOTITE.

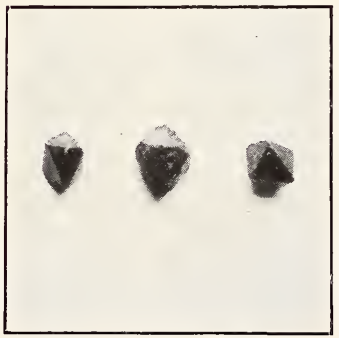

FIG. 11.-MAGNETITE.
FIG. 9.-MUSCOVITE.

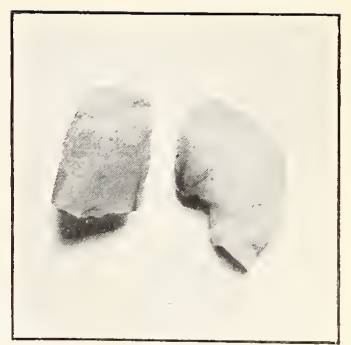

FIg. 3.-PLAGIOCLASE.

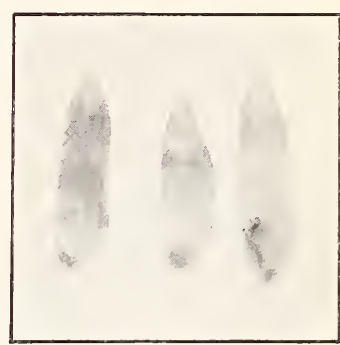

Fig. 6.-Calcite.
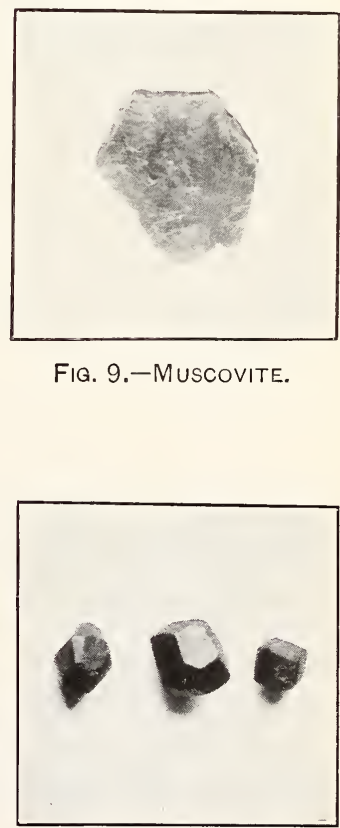

Fig. 12.-GARnET. 


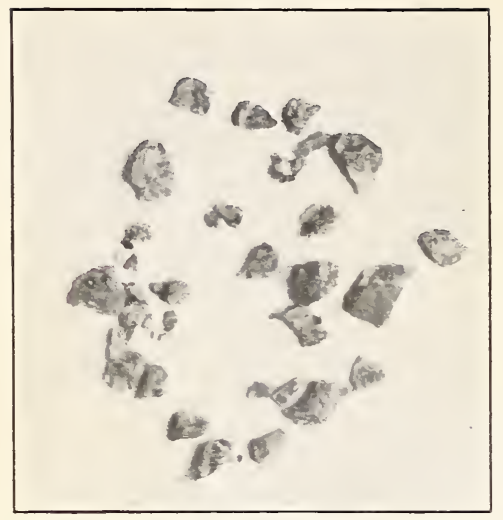

Fig. 1.-Granite.

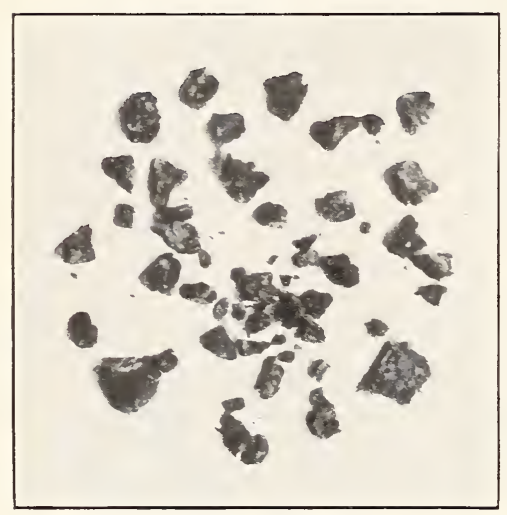

FIG. 3.-GABBRO.

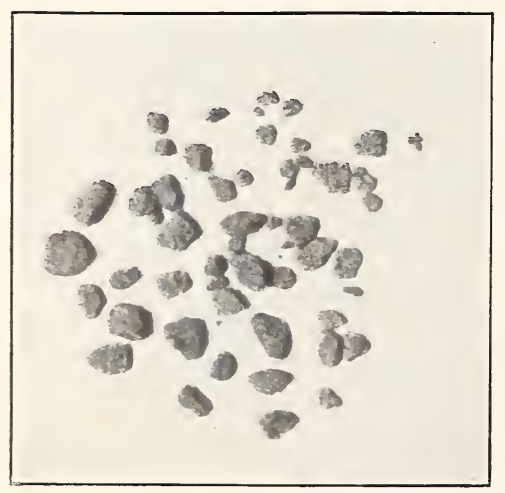

Fig. 5.-SANDSTONE.

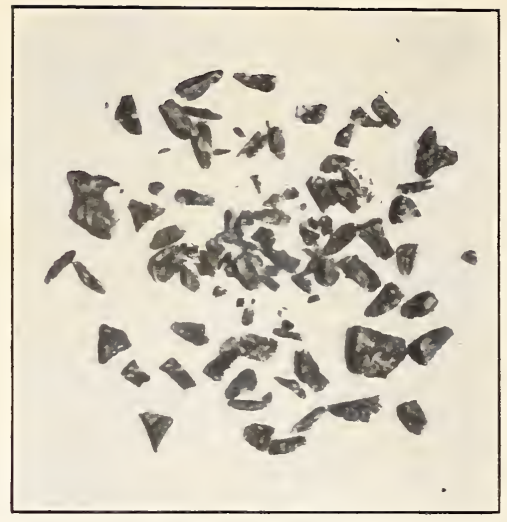

FIa. 2.-RHYOLITE.

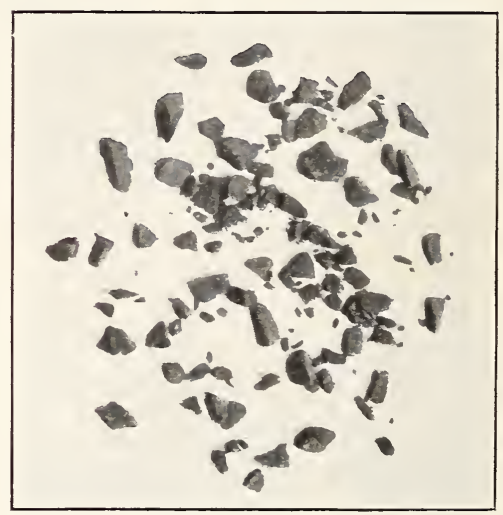

FIG. 4.-DIABASE.

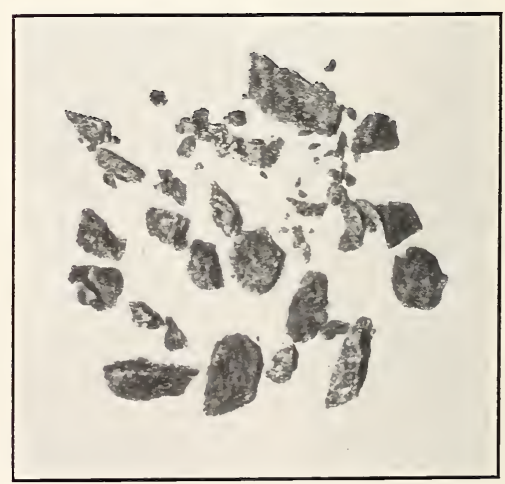

FIG. 6.-SCHIST. 
Furthermore, the microscope reveals certain peculiarities which are not discernible with the naked eye. Thus, plagioclase feldspar crystals (Pl. VII, fig. 3), that appear perfectly homogeneous in the hand sample, are seen under the microscope to be made up usually of a great number of smaller individual crystals arranged in a characteristic manner, or again, certain constituents such as augite and hornblende (Pl. VII, figs. 4 and 5) are distinguished by microscopic lines of parting (cleavage) that intersect at definite angles quite distinct from each other. As these minerals all differ in chemical composition, their optical properties are also different; that is, when light passes through a transparent thin section of a rock under a microscope with properly adjusted Nicol prisms, certain minerals will appear in beautiful rainbow colors, while in others these interference colors may be of a lower order and much fainter. Again not infrequently some components are encountered that show no optical reaction whatever and remain consequently dark through an entire revolution of the microscopic stage. These characteristic optical properties greatly facilitate the identification of the various rockforming constituents.

The chemical composition of a rock magma necessarily influences or controls the formation of minerals within the rock. Thus certain magmas, rich in silica and potash, embracing so-called acid rocks, produce on cooling light-colored granite and rhyolite (Pl. I, figs. 1 and 2), composed chiefly of quartz, orthoclase, and mica (Pl. VII, figs. 1, 2, 8, and 9); while other magmas having less silica and more iron and lime give rise to darker basic or trap rocks, such as diorite, gabbro, diabase, and basalt (Pls. II and III), made up chiefly of hornblende, plagioclase, augite, and magnetite (Pl. VII, figs. 3, 4, 5 , and 11). The mineral components of sedimentary rocks are dependent in composition on the character of the materials from which their sediments were derived, as well as upon the nature of the matrix cementing them. Calcareous deposits, therefore (Table 1, Nos. 15-16), derived chiefly from shell fragments (Pl. V, fig. 2), consist essentially of calcite and dolomite (Pl. VII, fig. 6), with varying amounts of quartz, kaolin, and iron oxide as impurities, while sandstones (Table 1, Nos. 17-20), formed from siliceous rock materials that have withstood the abrasive effects of transportation, are made up mainly of quartz and kaolinized feldspar fragments cemented together by calcite, limonite, or silicified clay (Pl. IV, fig. 1). Chert, or flint (Pl. IV, fig. 2), differs somewhat from a normal sandstone in that it is composed chiefly of very finely divided quartz frequently associated with opaline silica that originated from minute siliceous shells of marine animals through a process of chemical solution and deposition. The minerals present in metamorphic rocks are similar to those of igneous and sedimentary origin with the subsequent develop- 
ment, through metamorphic agencies, of muscovite, chlorite, epidote, hornblende, garnet, etc. (Pl. VII, figs. 5, 7, 9, 10, and 12). Thus it has been found that granite passes over into gneiss and micaceous schist (Pl. VI), and from the more basic gabbro, diorite, etc., are developed amphibolite, chlorite schist, eclogite, etc., while sandstone and limestone give place, respectively, to quartzite (Pl. V, fig. 1) and marble.

The chief interest attached to the study of these minerals is to determine in what manner they affect the road-making qualities of rocks, and it will be, therefore, of interest to discuss somewhat in detail their more important physical properties.

In Table 3 are given the essential mineral constituents of rocks for road making, with their general chemical composition and volumetric percentages as determined from all samples thus far analyzed.

TABLE 3.-Mineral constituents of rocks for road making.

\begin{tabular}{|c|c|c|c|c|c|}
\hline \multicolumn{3}{|c|}{ Primary minerals. } & \multicolumn{3}{|c|}{ Secondary minerals. } \\
\hline Name. & Chemical composition. & $\begin{array}{l}\text { Voln- } \\
\text { metric } \\
\text { per- } \\
\text { centages. }\end{array}$ & Name. & Chemical composition. & $\begin{array}{c}\text { Volu- } \\
\text { metric } \\
\text { per- } \\
\text { centages. }\end{array}$ \\
\hline Quartz. & Silica ......................... & 17.8 & Calcite. & Carbonate of lime......... & 26.5 \\
\hline Plagioclase. & $\begin{array}{l}\text { Silicate of alumina, lime, } \\
\text { and soda. }\end{array}$ & 9.6 & Dolomi & $\begin{array}{l}\text { Carbonate of lime and mag- } \\
\text { nesia. }\end{array}$ & 10.4 \\
\hline Orthoclase... & $\begin{array}{l}\text { Silicate of alumina and } \\
\text { potash. }\end{array}$ & 8.8 & Kaolin & Hvdrous silicate of alumi- & 4. 2 \\
\hline Augite. & Silicate of lime, magnesia, & 6.0 & Chlorite. & Hydrous silicate of mag- & 2.7 \\
\hline Hornblende. & $\begin{array}{l}\text { iron, and alumina. } \\
\ldots . . \text { do................. }\end{array}$ & 3.1 & Epidote. & $\begin{array}{l}\text { nesia, iron, and alumina. } \\
\text { Hvdrous silicate of lime. }\end{array}$ & 1. 7 \\
\hline Muscovite.... & Hrdrous silicate of alumi- & 2.4 & Limonit & Hydrated oxide of iron... & 1.2 \\
\hline Biotite.. & $\begin{array}{l}\text { Hydrous silicate of alumi- } \\
\text { na, iron, magnesia, and } \\
\text { potash. }\end{array}$ & 1.7 & Serpentine. & $\begin{array}{l}\text { Hydrous silicate of iron } \\
\text { and magnesia. }\end{array}$ & 0.1 \\
\hline Rock glass... & Variable.................... & 1.5 & Talc: & Hydrous silicate of mag- & 0.1 \\
\hline Magnetite... & Magnetic oxide of iron.... & 1.2 & Zeolite. & Hrdrous silicate of alumi- & 0.1 \\
\hline Garnet. & $\begin{array}{l}\text { Silicate of alumina, iron, } \\
\text { and lime. }\end{array}$ & 0.2 & Opal. & $\begin{array}{l}\text { na, me, and soda. } \\
\text { Hydrated silica....... }\end{array}$ & 0.1 \\
\hline
\end{tabular}

It will be noted that these constituents have been divided into two groups-primary minerals, or such that constitute the original components of igneous rocks and form the essential part of metamorphic schists, and secondary minerals that have been derived from the former through subsequent processes of alteration.

In the case of certain volcanic rock magmas (basalt, rhyolite, andesite), where the rate of cooling has been very rapid, a glass base (rock glass) is frequently left after crystallization has ceased. This glass is extremely brittle and when present in appreciable quantities has a tendency to lower the indicated wearing properties of the rock. 
PRIMARY MINERALS.

Quartz (Pl. VII, fig. 1) is without doubt the most widely distributed mineral in the earth's crust and is found in greater or less abundance in all kinds of road materials excepting the more basic types of unaltered igneous rocks (traps) and certain varieties of basic crystalline schists (amphibolites, eclogites). It has a specific gravity of 2.66 and is extremely hard, standing No. 7 in the Mohs scale of hardness. ${ }^{1}$ It is characterized in the rock sample by irregular, rounded shape, without parting planes (cleavage), and breaks readily into splintery glass-like fragments. Quartz sometimes appears as a secondary mineral in finely crystalline aggregates (chalcedony), often associated with opal or hydrated silica. It will be shown later on that where quartz is present in large quantities, especially when firmly consolidated, as in the case of fine-grained igneous and massive metamorphic rocks, the resulting material is extremely hard and offers great resistance to wear.

Orthoclase (microcline) and Plagioclase feldspars (Pl. VII, figs. 2 and 3) are among the principal ingredients of igneous and metamorphic rocks and certain types of sandstones. They vary in specific gravity from 2.54 to 2.76 , according to composition, and in hardness from 6 to 6.5. (Mohs scale.) These minerals occur as rock constituents frequently in well-defined, tabular-formed or lath-shaped crystals characterized by perfect cleavage along planes at, or approaching, right angles to each other. Because of this cleavage, many coarsegrained feldspathic rocks break down readily under impact into fragments having very characteristic cubical shapes. When present, however, in fine-grained aggregates closely intergrown with quartz, augite, or other minerals, the effect of cleavage is not apparent and the resulting rocks are extremely hard and tough.

Augite and Hornblende (Pl. VII, figs. 4 and 5) form the chief ironbearing or dark silicate constituents of basic igneous rocks (traps) and the crystalline schists derived from them. They have a hardness of 5 to $6.5,{ }^{2}$ specific gravity of 2.93 to 3.71 , and occur usually in more or less elongated, prismatic shapes, with well-defined cleavage parallel to the prism planes. Owing to their peculiar form, these crystals interlock very compactly with adjoining minerals, especially lath-shaped, plagioclase feldspar, thereby developing the most durable types of road material (traps).

Biotite (black mica) and Muscovite (white mica) are at home chiefly in granitic rocks and in micaceous schists and gneisses. Their specific gravity varies from 2.7 to 3.2 , with hardness of from 2 to $3 .^{2}$

1. This scale as described in Merrill's Rocks, Rock-weathering and Soils, p. 12, is based upon the relative hardness of the following minerals arranged in ascending order: (1) Talc, (2) gypsum, (3) calcite, (4) fluorite, (5) apatite, (6) orthoclase, (7) quartz, (8) topaz, (9) corundum, and (10) diamond.

2 Mohs scale.

$17715^{\circ}-$ Bull. $348-16-2$ 
Common mica is readily recognized in the hand sample by a thin plate-like crystal form, frequently with hexagonal outline (Pl. VII, figs. 8 and 9) and more especially by a perfect basal cleavage which causes the crystals to part readily into thin elastic flakes. The foliation characterizing many types of metamorphic rocks is caused largely by the parallel arrangement of mica laminæ, which is also largely responsible for the poor wearing properties of this material.

Magnetite and Garnet (Pl. VII, figs. 11 and 12) are found as essential constituents in but two types of road material (peridotite and eclogite). They occur in well-defined crystal form without cleavage and are extremely heavy (specific gravity 5.18-3.15), and hard $\left(5.5-7.5^{1}\right)$ and in some cases materially increase the wearing properties of the rock. (See Table 7, No. 13.)

Besides the abore-mentioned primary minerals others are found widely distributed in rarious kinds of road materials, but generally in such small quantities as not to affect appreciably the physical character of the rocks. Among these accessory constituents may be mentioned hypersthene, olivine, titanite, apatite, zircon, and pyrite.

\section{SECONDARY MINERALS.}

Under secondary minerals will be considered only the more important products of rock decay brought about mainly by the chemical action of water and carbonic acid on primary rock constitutents.

Calcite and Dolomite (Pl. VII, fig. 6) are the chief constitutents of limestones and dolomites and so far as they have formed upon the first consolidation of this material might consistently be classed as primary. In all other rock types these carbonates are distinctly of secondary origin and formed by the chemical combination of carbonic acid with lime and magnesia derived either directly from the disintegration of primary constitutents or introduced later from extraneous sources. These minerals have approximately the same physical properties and can not be separated microscopically, but may be readily distinguished by their different behavior toward cold dilute acids; calcite being readily dissolved with rigorous ebullition of carbonic acid gas, while dolomite is rery slowly acted on with barely perceptible effervescence. Calcite and dolomite are soft minerals (hardness $3-3.5^{1}$ ), of moderate specific gravity (2.62.9 ), and occur always in a crystalline condition. The crystals are characterized by perfect cleavage in three directions corresponding with the planes of a rhombohedron and for this reason calcareous rocks as a rule break down readily into fine crystalline powders.

Kaolin is a very common product of rock decay, especially in temperate climates, and is derived to a large extent from orthoclase 
feldspar (Pl. VII, fig. 2) through a process of hydration and dissolution by which all of the potash and two-thirds of the silica present in the feldspar may be removed. Under somewhat different conditions of weathering secondary white mica (sericite) will result in place of kaolin, whereby the same amount of silica but only onethird of the potash originally present in the orthoclase are lost. ${ }^{1}$ As the final product of feldspathic rock decay, kaolin is found, usually in large quantities, in clays and similar residual deposits. ${ }^{2}$ Kaolin occurs either in well-defined, small crystal plates (kaolinite) resemling muscovite (Pl. VII, fig. 9), in physical properties (hardness $2-2.5,{ }^{3}$ specific gravity $2.6-2.63$ ), or in the form of minute, amorphous grains of very indefinite composition, often associated with iron oxide and opaline silica. In this condition kaolin acts as a colloid and influences very greatly the plasticity and cementing value of rock powders by increasing in volume, and becoming glue-like when wet and binding the mineral particles firmly together when dry.

Chlorite and Epidote (Pl. VII, figs. 7 and 10) are frequently associated as alteration products of augite, hornblende, dark mica (biotite), and plagioclase, and are consequently most abundant in trap rocks or in darker varieties of crystalline schists (Table 1, Nos. 12, 14, and 26). The process of alteration is similar to that already stated regarding kaolin and the products themselves are in many cases not unlike this mineral in physical properties. Chlorite is a soft green mineral found either in the form of well-developed, thin plates and folia resembling mica, or as very fine scales and fibers of indefinite composition (viridite) frequently accompanied by amorphous silica, calcite, and iron oxide. In the latter development, chlorite bears a close resemblance to kaolin in its effects on the cementing properties of road materials.

Epidote in contrast to chlorite, occurs as granular or prismatic crystal aggregates, derived chiefly from plagioclase feldspar when accompanied by iron-bearing compounds. It is a hard $\left(6-7^{3}\right)$, tough mineral with high specific gravity (3.25-3.5), yellowish green color and, when present in appreciable quantities, apparently increases the wearing qualities of rocks.

Other secondary minerals.-Among other products of rock decay may be mentioned limonite, serpentine, talc, opal, and zeolitic compounds. These minerals are, with the exception of the harder crystalline zeolites (chabazite and natrolite), very indefinite in crystal form or entirely amorphous (opal and limonite), and are not readily separated by means of the microscope.

1 H. Rosenbusch, Elemente der Gesteinslehre, 3d edition, p. 79.

2 H. Niklas: Die Kolloidchemie und ihre Bedeutung für Bodenkunde, Geologie und Mineralogie. Inter. Mittl. für Bodenkunde, Vol. III, 1913, p. 395.

${ }^{3}$ Mohs scale. 


\section{PHYSICAL PROPERTIES OF ROAD MATERIALS.}

From what has been said it is apparent that many kinds of minerals associated in different ways enter into the composition of rocks for road building. It will now be of interest to discuss briefly the physical properties of the rocks themselves before taking up more specifically the relationship between these properties and the mineral composition and structure of road materials.

The physical properties selected for this investigation are expressed upon determination by laboratory tests, as follows: (1) Per cent of wear or loss by abrasion, (2) hardness, (3) toughness, (4) cementing ralue, and (5) specific gravity.

Per cent of wear represents the amount of material under 0.16 $\mathrm{cm}$. in diameter lost by abrasion from a quantity of rock fragments as nearly uniform in size as possible and weighing within 10 grams of 5 kilograms. This carefully weighed sample which should contain about 50 pieces of rock is tested in a Deral type of abrasion machine consisting of a cast-iron cylinder, $34 \mathrm{~cm}$. deep by $20 \mathrm{~cm}$. in diameter, closed at one end and having a tight-fitting cover at the other. The cylinder is attached to a horizontal shaft so that the axis is inclined at an angle of $30^{\circ}$ with that of the shaft and revolved for 5 hours at the rate of 2,000 revolutions per hour, during which the rock fragments are thrown from one end of the cylinder to the other twice in each revolution. This abraded material is then thoroughly dried and screened through a $\frac{1}{16}$-inch mesh sieve and from the amount lost the per cent of wear is determined. This loss may be also expressed by the French coefficient given below:

$$
\text { Coefficient of wear }=20 \times \frac{20}{\mathbb{W}}=\frac{400}{\mathrm{~W}}=\frac{40}{\text { per cent of wear }}
$$

where $\mathrm{W}$ is the weight in grams of the abraded material under 0.16 cm. ( $\frac{1}{16}$ inch) in diameter per kilogram of rock used. ${ }^{1}$

Hardness is the resistance which a material offers to the displacement of its particles by friction and the test is made on a cylindrical rock core, 25 millimeters in diameter. The test piece is held perpendicularly under a constant pressure of 1,250 grams, against a rerolring cast-steel disk, while standard quartz sand, between 30 and 40 mesh, is used as the abrasion agent. From the average loss in weight computed from two runs, the coefficient of hardness is obtained by deducting one-third of this loss, expressed in grams per 1,000 revolutions, from an arbitrary constant (20).

Toughness, as here understood, is the resistance a material offers to fracture by impact. The test piece is a cylindrical rock core 25 millimeters high by 25 millimeters in diameter, and the test is made 
with an impact machine constructed on the principle of a pile driver. The blow is delivered by a hammer weighing 2 kilograms, raised by a sprocket chain and released automatically by a concentric electromagnet to fall on an armor-piercing steel plunger with spherical lower end which is in contact with the upper surface of the test piece. The test consists of a 1 centimeter fall of the hammer for the first blow and an increased fall of 1 centimeter for each successive blow until failure of the test piece occurs. The number of blows required to cause rupture represents the toughness.

The cementing value is the property possessed by a rock dust to cement or bind together the coarser rock fragments, and the test is carried out as follows: One-half kilogram of rock is broken sufficiently small to pass a half-inch-mesh screen and is then moistened with 90 cubic centimeters of water and placed in a cast-iron ball mill, containing two cast-steel shot, 5 inches in diameter and weighing about 20 pounds each. The sample is ground for $2 \frac{1}{2}$ hours at the rate of 2,000 revolutions per hour or until the material has been reduced to a thick dough, the particles of which are not above 0.25 millimeter in diameter. The dough is then removed and molded into cylindrical briquettes 25 millimeters in diameter and 25 millimeters high, in a hydraulic briquette-forming machine, so adjusted as to give a maximum momentary pressure of 132 kilos per square centimeter on the compressed material. Five briquettes are made from each test sample which, after being thoroughly dried at $200^{\circ} \mathrm{F}$. and cooled in a desiccator, are broken by an especially designed impact machine having a 1-kilogram pendulum hammer with an effective drop of 1 centimeter. The average number of blows required to destroy the bond of cementation in five briquettes determines the cementing value of the rock sample.

Specific gravity is the weight of the material compared with that of an equal volume of water, and is obtained by dividing the weight in air of a rock fragment by the difference between its weight in air and water. The weight per cubic foot of rock is found by multiplying the specific gravity by 62.37 pounds, the weight of a cubic foot of water.

\section{GENERAL RELATION BETWEEN THE PHYSICAL PROPERTIES OF ROCKS AND THEIR MINERAL COMPOSITION AND STRUCTURE.}

The general relation of rocks as expressed by average mineral composition and physical properties may be seen from the results of the tests and analyses given in Table 1 . In the first place it will be noticed that igneous rocks as a class (Nos. 1-14), owing to their more uniform structure and preponderance of hard silicate components, have better indicated wearing properties than either sedimentary rocks or crystalline schists. As previously stated, these igneous rocks 
have been separated into plutonic (Nos. 1-7) and volcanic varieties (8-14). The former, embracing rocks of granitic character, are in general less tough and have indicated wearing properties inferior to their finer-grained, volcanic equivalents. This may be ascribed directly to their coarser grain and to the marked effect of feldspathic cleavage (see p. 7). It will be observed, furthermore, that among the plutonic rocks those varieties unusually rich in mica (No. 2) and secondary serpentine (No. 7) have exceptionally low indicated wearing properties, whereas samples containing hornblende and augite in appreciable quantities are relatively tougher and in general offer greater resistance to abrasion (Nos. 3-6). In regard to the cementing value of plutonic rocks it will be seen that the quartzose varieties (Nos. 1, 2, 3, and 5) are lower than types in which quartz is absent, or present only in subordinate quantities (Nos. 4, 6, and 7).

The high toughness and excellent indicated wearing properties of volcanic rocks is in accordance with their fine grain and close interlocking mineral structure. The results of the tests indicate that siliceous varieties (No. 8) are on the whole harder though less tough than the more basic rocks to which trap belongs (Nos. 9-14). It will be observed, also, that samples rich in glass (Nos. 10, 11, and 12) are lower in hardness and toughness than their corresponding wholly crystalline varieties (Nos. 13 and 14). The latter are, furthermore, characterized in general by a peculiar intergrowth of plagioclase and augite (ophitic structure) which indicates greatly increased durability. (Pl. III). The average cementing values of tresh trap varieties (Nos. 11 and 13) are much below the corresponding varieties that have undergone alteration (Nos. 12 and 14), although superior to the latter in other respects.

Considering briefly the group of sedimentary rocks (Nos. 15-20) it will be noted that they are characterized in general by a lower toughness and hardness and higher per cent of wear, owing to the presence of soft, readily cleavable calcite and dolomite, as well as to a more open texture resulting in the case of the sandstones from incomplete cementation. (See p. 4.)

Metamorphic rocks have been divided into foliated (Nos. 21-28) and nonfoliated or massive varieties (Nos. 29-35). The former, owing to the peculiar parallel arrangement of their mineral constituents or schistose structure (Pl. VI) are comparatively low in toughness and indicated wearing properties except when hornblende is present in appreciable quantities (Nos. 27 and 28). Nonfoliated varieties, on the other hand, representing the direct result of compact crystallization without shearing of quartz, and hard silicates such as hornblende, augite, epidote, and garnet, are exceptionally hard and tough but usually deficient in cementing properties (Nos. 30-34). 
The before-mentioned differences in physical properties of rocks for road making find expression also in the shapes of their smaller fragments as shown in Plate VIII.

It will be observed that the screenings from coarse-grained plutonic rocks after removal of the fine dust (figs. 1 and 3) are more rectangular in shape than those from finer-grained volcanics of similar composition which appear splintery and wedge-shaped (figs. 2 and 4). These characteristic shapes may be ascribed, as previously indicated, to the cubical cleavage of coarse, granular feldspar in the plutonic rocks and to the denser structures developed in the finer-grained rock types. The peculiar rounded shape of more loosely textured sandstones and the flat, lath-like appearance of fragments from schistose rocks (figs. 5 and 6 ) are noteworthy and may be associated directly with the mode of origin and mineral composition of this material. (See pp. 4-6.)

Regarding the binding effect of these rock types on the road it can be stated in general that the tough wedge-shaped fragments from fine-grained igneous rocks are inclined to produce a firmer and more permanent bond with the coarser road stones when properly compacted than is obtained with the more cubical or rounded screenings from granite and sandstone or with the lath-shaped schists and gneisses. This interlocking of the coarser rock fragments under the roller may be termed the mechanical bond of the road surface as distinguished from the cementing bond or binding effect produced by the finer rock dust when sufficiently moistened and compressed. In discussing the mineral composition of road materials this cementing property has been attributed largely to the peculiar quality of certain amorphous compounds closely related to kaolin and chlorite in composition. It will now be of interest to compare varying proportions of these compounds as well as other secondary minerals found in the more common rock types and note their effect on the cementing value and other physical properties of the rocks.

\section{THE EFFECT OF SECONDARY MINERALS ON THE PHYSICAL PROPERTIES OF ROCKS FOR ROAD BUILDING.}

The majority of rocks used for road building have been obtained from near the earth's surface or within the zone of atmospheric weathering, ${ }^{1}$ and the extent of alteration varies greatly, depending upon composition, rock structure, and character and time of operation of the agencies involved. The resulting minerals are also manifold, being either softer products of hydration and oxidation, such as kaolin, chlorite, limonite, calcite, and opaline silica, or the harder silicates, epidote and zeolite, accompanied in some cases by secondary hornblende (actinolite) and quartz resulting from deeper-

${ }^{1}$ G. P. Merrill, Rocks, Rock-Weathering and Soils, 1906, p. 152. 
seated processes of alteration. The effect of these secondary compounds is best demonstrated by arranging the various members of each rock class, so far as possible, into groups having approximately the same average proportions of alteration products.

\section{IGNEOUS ROCKS.}

In view of the great structural differences shown in rocks of this class it will be found of advantage to discuss separately the coarsegrained plutonic and fine-grained volcanic varieties. In Table 4 the average mineral composition and physical properties of plutonic rocks are given, arranged so far as possible in family groups having approximately like percentages of secondary constituents. These groups indicate an average of all samples having less than 5 per cent, from 5 to 10 per cent, and more than 10 per cent secondary minerals.

It will be observed in general that for a given family the toughness and hardness of these rocks tend to increase and the per cent of wear tends to decrease with additional amounts of secondary minerals, excepting in the case of very soft, highly kaolinized gabbro and serpentinized peridotite (Nos. 11 and 12). This improvement is less noticeable in granitic rocks (Nos. 1, 2, and 3) than in more basic varieties (Nos. 4-10) and may be attributed to the partial replacement of plagioclase feldspar by hard granular epidote (Nos. 3 and 5), accompanied in some cases by zeolites (No. 8) or actinolitic hornblende (No. 10). ${ }^{1}$ The influence of secondary constituents is more apparent in regard to cementing value than to other properties. Thus it will be noted that altered varieties have a higher binding value than fresher samples and that the increase is roughly proportional to that of the secondary minerals. This increase, moreover, varies greatly in different rock types, reaching a maximum of 9 in the case of granites (Nos. 1-3), 31 in diorites (Nos. 6-8), 87 in gabbros (Nos. 9-11), and 92 in syenites (Nos. 4 and 5). It will be observed, furthermore, that the cementing value of siliceous varieties are in inverse relation to their quartz content. That is to say, granites, diorites, and syenites with averages of 28,8 , and 4 per cent quartz, respectively, have corresponding cementing values of 20,34 , and 90 , indicating that the binding properties of coarse-grained rocks may be largely influenced by the physical character of the primary mineral components.

The effect of secondary minerals on the physical properties is more clearly demonstrated in the following group of volcanic rocks. This group embraces all fine-grained varieties of igneous rocks that, as shown in Table 5, are especially adapted to road building. The rocks have been arranged in families containing approximately like proportions of secondary minerals, obtained in the case of rhyolite and 
PHYSICAL PROPERTIES OF ROAD MATERIALS.

\begin{tabular}{|c|c|c|c|c|c|c|}
\hline \multirow{5}{*}{ 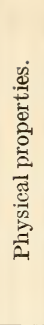 } & 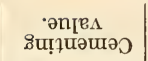 & $\stackrel{\infty}{\infty}$ 族 & 우유 & ลิะี & פద్రి & $\stackrel{e}{1}$ \\
\hline & •ssəuบร̊noJ & 고크고 & $\dddot{m}=$ & 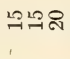 & 걱 주음 & $=$ \\
\hline & 'ssәupreH & $\dot{\infty} \dot{\infty} \dot{\infty}$ & $\begin{array}{l}\sim \sim \\
\infty \\
\infty\end{array}$ & $\begin{array}{l}0 \sim \sim \\
\therefore \dot{\infty} \\
-\infty\end{array}$ & 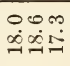 & $\begin{array}{l}\sim \\
\dot{J}\end{array}$ \\
\hline & Јо & 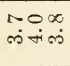 & $\begin{array}{l}0 \\
\dot{m} \dot{\infty}\end{array}$ & भंต் & 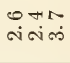 & $\stackrel{\circ}{\rightarrow}$ \\
\hline & 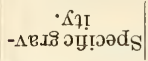 & 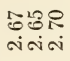 & $\begin{array}{l}\text { B̊ } \\
\text { NiN }\end{array}$ & 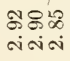 & $\begin{array}{l}\text { B\&\& } \\
\text { तivi }\end{array}$ & $\begin{array}{l}\mathscr{Z} \\
\text { i }\end{array}$ \\
\hline \multirow{9}{*}{ 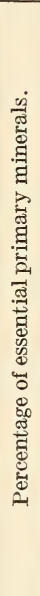 } & 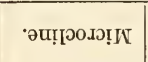 & $\begin{array}{l}0.00 \\
\text { Hision }\end{array}$ & $\begin{array}{l}\text { O० } \\
\text { İं i }\end{array}$ & & & : \\
\hline & •ə१!ุวนระณ & & & & & $\ddot{\infty}$ \\
\hline & •əาเา०เต & $\begin{array}{l}\infty \infty 0 \\
\dot{100} \dot{0} \dot{0}\end{array}$ & $\ddot{~ क े म े ~}$ & 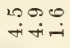 & & \\
\hline & 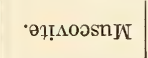 & $\begin{array}{l}\text { Nito } \\
\text { Niti }\end{array}$ & & & & $\vdots$ \\
\hline & •өриәгчилон & & & வீ: & $\begin{array}{l}0.120 \\
\text { Nidi }\end{array}$ & $\vdots$ \\
\hline & •əษ!ภำ & & $\begin{array}{ll}\infty & 0 \\
\infty & 0\end{array}$ & & 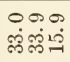 & $\begin{array}{l}0 \\
\dot{\infty}\end{array}$ \\
\hline & 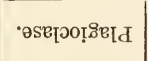 & $\begin{array}{l}\infty 000 \\
\infty \infty 00\end{array}$ & $\begin{array}{l}128 \\
\infty 120\end{array}$ & 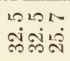 & 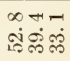 & \\
\hline & • әรеโวочา. IO & 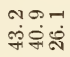 & 品 & $\begin{array}{l}\text { Wos } \\
\infty\end{array}$ & $\vdots$ & $\vdots$ \\
\hline & "zqueno & $\begin{array}{l}000 \\
\text { ลंज्ञ }\end{array}$ & $\begin{array}{l}\infty \infty \\
\text { +ioi }\end{array}$ & $\begin{array}{l}+\infty \infty \\
\dot{\infty} \dot{\infty} \infty\end{array}$ & & : \\
\hline \multirow{7}{*}{ 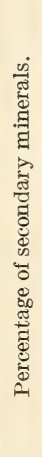 } & 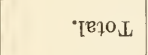 & बing & $\stackrel{\infty}{-\infty}$ & $\begin{array}{l}\theta \dot{\theta}: 0 \\
\text { बi: }\end{array}$ & : & $\stackrel{\infty}{\infty}$ \\
\hline & 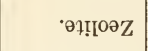 & & & $\vdots$ & & $\vdots$ \\
\hline & 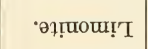 & $\ddot{0}$ & ن. & $\ddot{0}: \dot{0}$ & $\vdots \begin{array}{l}+\infty \\
00\end{array}$ & $\stackrel{m}{0}$ \\
\hline & •әา!७โอว & $\because \div 00$ & $\ddot{0 N}$ & $\begin{array}{l}-01 \\
000\end{array}$ & $\vdots \begin{array}{c}0 \\
\vdots\end{array}$ & $\vdots$ \\
\hline & • $\theta 7 !$ sop!d & $\begin{array}{l}m \infty \\
\dot{0} \dot{\sigma}\end{array}$ & $\vdots$ & 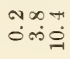 & $\begin{array}{l}\text { os } \\
0 \text { is }\end{array}$ & \\
\hline & •u!̣oвy & 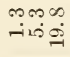 & $\stackrel{0}{-i \infty}$ & $\begin{array}{l}20-10 \\
-1200 \\
-100\end{array}$ & 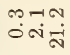 & \\
\hline & 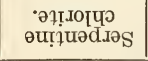 & 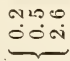 & $\underbrace{-100}$ & $\underbrace{-1+\pi}$ & 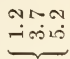 & ลิ \\
\hline & 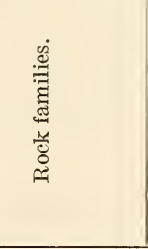 & ـ & 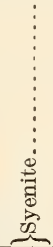 & $\underbrace{\vdots}$ & 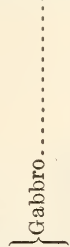 & 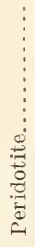 \\
\hline & 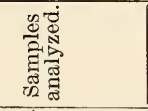 & 우유 & $\infty \varrho$ & ลีสีค & $\stackrel{\infty}{\infty} \infty$ & r \\
\hline & 光它 & - & A2 & $\infty \sim \infty$ & $\cos =$ & 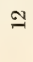 \\
\hline
\end{tabular}




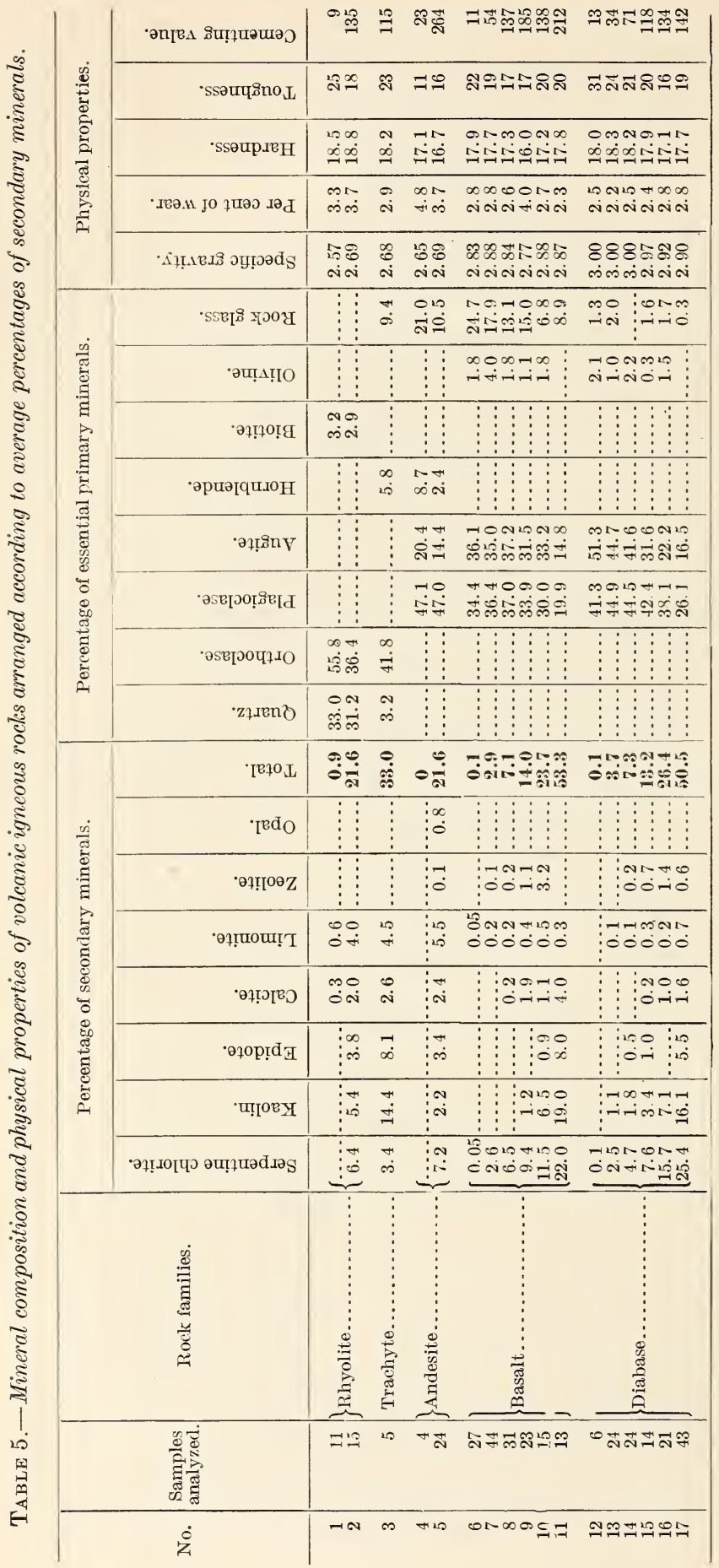


andesite by averaging the analyses of fresh and altered varieties; and in the case of basalt and diabase, by averaging samples containing less than 1 per cent, from 1 to 5 per cent, from 5 to 10 per cent, from 10 to 20 per cent, from 20 to 30 per cent, and all above 30 per cent, of secondary minerals.

It will be observed in the first place that, in contrast to coarsergrained plutonic rocks the toughness and hardness of unaltered volcanics (Nos. 1, 6, and 12) are as a rule superior to those that have suffered from the effects of weathering. Exceptions will be noted, however, in the case of unaltered vitreous andesites (No. 4), which are low in toughness and indicated wearing properties on account of excessive glass content, and in that of certain highly altered varieties of trachyte, andesite, basalt, and diabase (Nos. 3, 5, 10, 11, and 17), which owe their relative high toughness and good indicated wearing properties to the development of hard secondary epidotes and zeolitic compounds combined with but little glass. The cementing values of volcanic rocks increase up to a certain point quite uniformly with increased proportions of alteration products, reaching a maximum in quartz-free rocks (Nos. 5, 11, and 17). Expressed numerically, this increase is 126 for rhyolite and 241 for andesite with equal percentages of secondary minerals (21.6 per cent), while basalt and diabase having about 50 per cent alteration compounds show a maximum increase of 201 and 129, respectively.

Comparing these results with the foregoing, it is apparent that the cementing property of volcanic rocks is on the whole superior to that of plutonic rocks having equal amounts of secondary minerals, and, furthermore, that this property is here less influenced by primary mineral composition-quartzose rhyolites binding almost as well as basalts (Nos. 1, 2, 6, and 10)-but is effected chiefly by differences in secondary compounds. This will be made clear by noting the average cementing values for basalt and diabase, which increase quite uniformly with the rate of decomposition where softer colloidal compounds, such as kaolin and chlorite prevail (Nos. 6-9 and 12-16). Beyond this point the presence of harder, more highly crystalline products of alteration (epidote, zeolite), indicating a less colloidal condition of the other secondary minerals, lowers the rate of increase (Nos. 11 and 17) or causes a falling off in binding properties (No. 10).

SEDIMENTARY ROCKS.

In discussing the origin of rocks it has been stated that road materials belonging to this class (limestones and sandstones) are formed chiefly by the cementing together of shell and mineral fragments or by chemical precipitation of amorphous silica (chert). While the mineral constituents of sandstones and cherts have been determined 


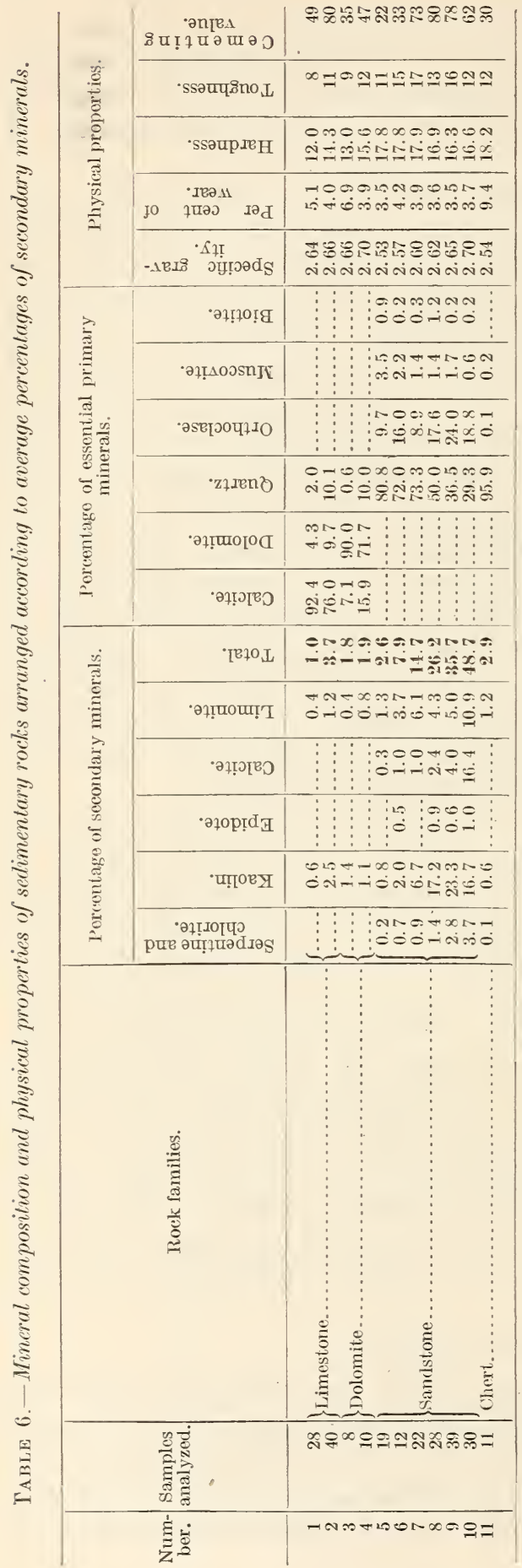


microscopically, it was found necessary to subject limestones and dolomites to chemical analysis by means of which quartz, kaolin, and limonite could be separated quantitatively from the carbonate minerals. The results of the physical tests and mineral analysis of sedimentary rocks are given in Table 6 . It will be seen that limestones and dolomites have been separated into groups having about equal quantities of quartz and secondary constituents, while sandstones have been divided into families representing averages of samples containing from 1 to 5 per cent, from 5 to 10 per cent, from 10 to 20 per cent, from 20 to 30 per cent, from 30 to 40 per cent, and above 40 per cent, of secondary minerals.

Comparing these results it will be observed in the first place that the average toughness and indicated wearing properties of calcareous rocks (Nos. 1-4) are as a rule inferior to sandstones (Nos. 5-10) while their cementing values are about the same. The exceptionally high percentage of wear found for chert (No. 11) may be explained by the fractured condition of this material caused by contraction on consolidation of the colloidal silica. ${ }^{1}$

It will be noticed, furthermore, that varieties of limestone and dolomite containing an appreciable amount of quartz with some kaolin or clay (Nos. 2 and 4) are tougher and have lower percentages of wear and higher cementing values than samples deficient in these minerals (Nos. 1 and 3). It would appear also that limestones, owing to their greater solubility in water, cement better than dolomites.

Turning to the sandstones it will be observed that their toughness and cementing values increase proportionately with secondary components up to rocks averaging about 15 per cent (No. 7) and that beyond this point a general falling off in hardness and toughness takes place while the cementing value remains practically constant or decreases slightly with proportionately increased amounts of calcite (Nos. 9 and 10). It should be stated, however, that not only the quantity and quality of cementing material present in this class of road material but also the fineness of grain and density of structure influences the physical properties to a very marked degree. ${ }^{2}$ Therefore it may be said that compact, fine-grained sandstones, having a moderate amount of siliceous clay cement (No. 7), produce harder and tougher material than rocks with deficient binder (Nos. 5 and 6 ) or such containing a large excess of calcareous clay cement (No. 10).

\section{METAMORPHIC ROCKS.}

The chief result of mineral alteration by metamorphic agencies is the development of highly crystalline rocks having characteristic structures, and composed of minerals very resistant to atmospheric weathering. For this reason the various types of foliated (Nos. 1-8)

1 Office of Public Roads, Bul. 37, p. 2־.

2 J. Hirschwald. Handbuch der bautechnischen Gesteinspruefung, 1912, pp. 360-484. 
BULLETIN 348, U. S. DEPARTMENT OF AGRICULTURE.

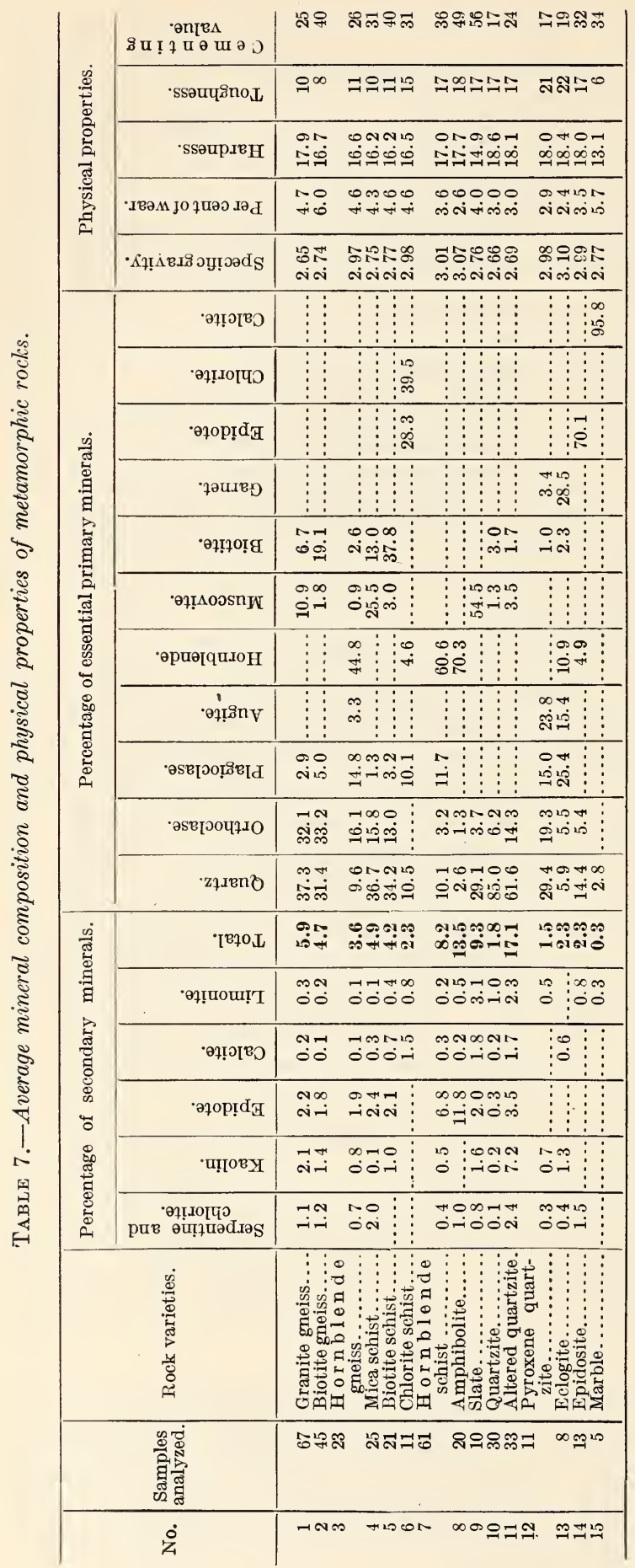


and nonfoliated (Nos. 9-15) metamorphic rocks, given in Table 7 contain relatively low percentages of secondary minerals, and have not been further subdivided, with reference to these, except in the sase of quartzites.

In comparing these rocks it will be noted that the foliated types, with the exception of more compact hornblendic varieties (Nos. 7 and 8), are lower in hardness, toughness, and indicated wearing properties than nonfoliated types excepting the highly micaceous slates (No. 9) and crystalline marbles (No. 15). It will be observed, furthermore, that the cementing value of metamorphic rocks is relatively low in

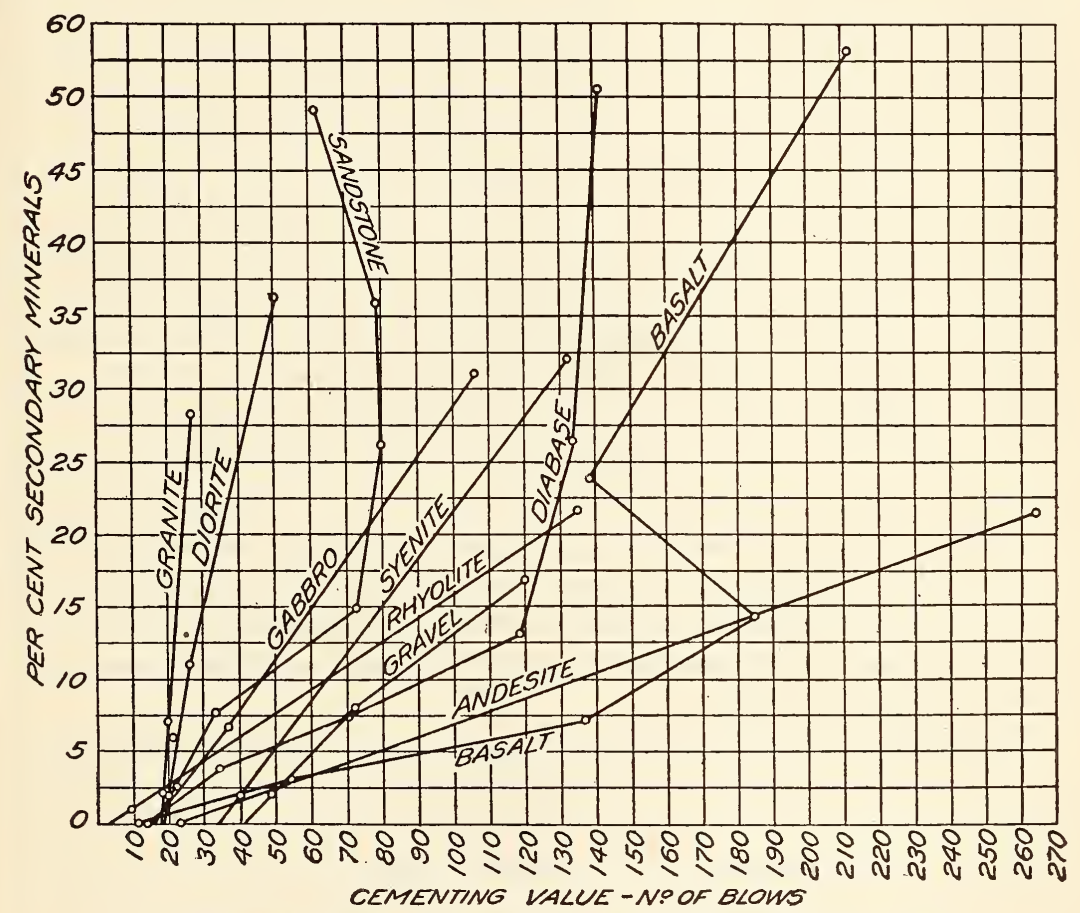

FIG. 3.-Effects of alteration products on cementing properties of rock powders.

accordance with low percentages of kaolin and secondary chlorite, reaching a maximum of 49 in amphibolite and 56 in slate (Nos. 8 and 9), with 13.5 per cent and 9.3 per cent, respectively, of secondary minerals, and a minimum of 17 in quartzites having each about 1.5 per cent decomposition products (Nos. 10 and 12). The very slight effect of even appreciable quantities of secondary minerals (No. 11) on the cementing properties of these highly quartzose rocks is similar to that found in acid granite (see p. 16), and may be attributed in both cases to the physical character of the quartz fragments combined with insufficient colloidal material. It will be of interest in this connection to compare these altered quartzites (No. 11), having 
an average cementing value of 24 , with decomposed sandstones showing an average binding ralue of 73 (Table 6, No. 7), and to note that the secondary products of the latter rocks consist almost entirely of colloids in the form of ferruginous clay (kaolin and limonite), while in the former crystalline epidote and chlorite are present in proportionately greater amounts.

The effects of alteration products on cementing properties of rock powders are shown in figure 3 , where varying percentages of secondary minerals in rocks and gravels have been plotted against their respective cementing values. The great difference in binding properties between quartzose plutonic rocks (granite and diorite) and quartzfree types of the same class (syenite and gabbro), as well as between plutonic and rolcanic rocks of similar composition, is clearly demonstrated. It will be observed also that where more complete curves could be drawn, as in the case of basalt, diabase, and sandstone, a critical point is reached at about 14 per cent of secondary minerals up to which the rate of increase in cementing value is almost directly proportional to that of these minerals, but beyond this point a marked deflection or break in the curves occurs in accordance with decreased cementing values resulting from largely increased proportions of highly crystalline products of alteration (epidote, zeolites, and calcite). The curve representing gravels from which the secondary minerals or clay content have been obtained by sifting through a 200-mesh screen and washing, indicates a relatively high cementing value up to samples containing 2 per cent clay, and shows that beyond this the relative increase corresponds in general to that of sandstone, reaching a maximum of 120 in samples having an average of 16.8 per cent of clay.

The property to slake in water is also common to many rock types, and as shown in Table 8 is largely dependent upon the physical character of the rock-forming constituents. The tests hare been made by placing thoroughly desiccated briquettes of rock powders in water and noting the time required for their complete disintegration. Briquettes remaining intact for 24 hours in water are considered nonslaking.

It will be observed that the samples tested have been separated into acid and basic crystalline rocks (Nos. 1-4) and siliceous sedimentary rocks (Nos. 5 and 6 ), and the average mineral composition, time of slake, and cementing ralue given in each case. In comparing the results it will be noted that the nonslaking acid rocks. (No. 1), while somewhat richer in secondary minerals, especially chlorite and epidote, contain a large excess of primary hornblende and considerably less quartz and mica than the slaking rarieties (No. 2), while their cementing values are about the same. Nonslaking basic and 
PHYSICAL PROPERTIES OF ROAD MATERIALS.

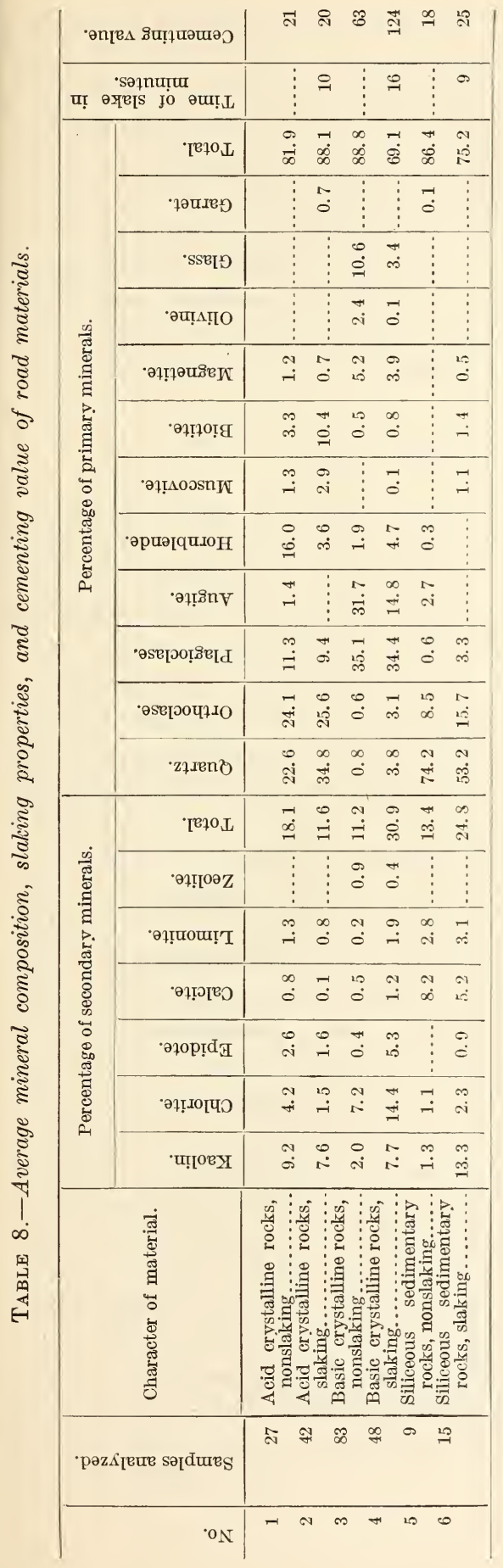


sedimentary rocks (Nos. 3 and 5), on the other hand, are distinguished from those that break down readily under water (Nos. 4 and 6 ) by a much lower percentage of colloidal secondary products (kaolin and chlorite) and by a corresponding decrease in cementing properties. From what has been said it is evident that basic crystalline and sedimentary rock powders with high cementing values and abundant secondary compounds have a marked tendency to slake, especially where the latter products are essentially colloidal in character, whereas the slaking property of acid crystalline rocks is influenced mainly by the relative abundance of primary quartz and mica and bears no very definite relation to secondary mineral composition and cementing properties.

\section{SUMMARY AND CONCLUSION.}

In the preceding pages a microscopic method of rock analysis by means of a crossline grating, has been reviewed and the average mineral composition and physical properties of all rocks analyzed and tested in this office up to January 1, 1914, have been presented in tabular form. This material has been classified according to composition and structure and the rock-forming constituents have becn discussed under the groups of primary and secondary minerals with a view to explaining their essential physical characteristics. The physical properties of rocks for road making and the method of testing this material have also been given and the results obtained used to show, first, in a general way, the relation between these properties and the mineral composition and structure of rocks; and secondly, to point out more specifically the effects of secondary compounds upon them. It has been found that igneous and nonfoliated metamorphic rocks owing to a preponderance of firmly united silicate minerals combined with uniformity in structure, offer a greater resistance to abrasion than other rock types, coarse-grained varieties being less tough and having inferior indicated wearing properties to those of finer grain in which the mineral components are more closely intergrown. Excessive quantities of glass in volcanic lavas and high percentages of readily cleavable mica and feldspar in plutonic rocks lower their toughness and indicated resistance to wear; on the other hand, appreciable quantities of hornblende and augite have an opposite effect. Foliated schists and gneisses parting readily along planes of schistosity are low in toughness while sandstones and limestones owe their inferior indicated resistance to wear either to incomplete consolidation or to a preponderance of softer carbonate minerals and clay. 
It has been demonstrated, furthermore, that the shape and physical character of the smaller rock fragments used in road making are largely dependent upon structure and mineral composition, coarsegrained feldspathic rocks breaking down readily into rectangular fragments owing to feldspar cleavage, whereas the finer-grained trap screenings are more wedge-shaped and tougher. The chips broken from loosely compacted sandstones and schists are rounded in shape, approaching somewhat the outline of abraded quartz grains, or they appear flat and lath-shaped in accordance with the foliated structure of the latter rocks. The effect of weathering on the physical properties of rocks is clearly shown and varies with the structural character and composition of the rock and the physical properties and relative abundance of alteration products. Thus the indicated wearing properties of igneous and metamorphic rocks are, in general, benefited by hard secondary epidote, zeolite, and hornblende, while an abundance of softer alteration products such as chlorite, serpentine, and kaolin lowers the indicated resistance to wear.

In sedimentary limestones and dolomites it has been found that quartz accompanied by a little kaolin has greatly increased their toughness and resistance to abrasion, whereas compact sandstones having about 15 per cent of secondary constituents are among the most resistant of sedimentary rocks. The effects of weathering have been found most pronounced in regard to the cementing property of road materials, which is seen to vary directly, but not in the same ratio, with the amount of soft secondary minerals, in part amorphous. Where these materials are replaced, even to a limited extent, by harder, more crystalline products of alteration the binding properties are proportionately lowered. These relations have been plotted in curves for the common crystalline rock types and gravels.

Finally, the slaking properties of rock powders have been investigated with the result that acid crystalline rocks are found to slake rapidly excepting samples that contain relatively low average percentages of mica and quartz and abundant hornblende and epidote, while the slaking qualities of basic igneous rocks and sandstones are dependent mainly on the relative abundance of colloidal products of rock weathering, such as kaolin, limonite, and chlorite.

The results obtained from the present investigations indicate the following:

(1) Igneous and nonfoliated metamorphic rocks, owing to a preponderance of hard silicate minerals combined with greater uniformity in structure, are more durable than other road-making materials, finer-grained varieties offering greater resistance to abrasion than coarse-grained types. 
(2) The resistance to wear of igneous and metamorphic rocks, containing an abundance of quartz, hornblende, augite, epidote, and garnet, is greater than that of similar rocks rich in mica, chlorite, serpentine, and calcite.

(3) Foliated metamorphic rocks, owing to the parallel arrangement of their mineral constituents, are, as a rule, deficient in toughness, and therefore not well adapted to road construction.

(4) Sedimentary rocks are usually deficient in wearing properties, except in the case of highly indurated sandstones, containing a moderate amount of siliceous clay, cement, and limestones or dolomites rich in quartz and having very little clay.

(5) Rocks for road making break down under impact into fragments, the shape and physical character of which are conditioned by mineral composition and structure.

(6) The effect of weathering is generally to lower the resistance to wear of road materials, owing to the development of soft, in part colloidal, products of alteration. Where the secondary minerals are harder and more crystalline the wearing properties of the rocks are proportionately increased.

(7) The cementing value of road materials is conditioned chiefly by the colloidal products of rock decay and increases in a general way proportionately with these products, reaching a maximum in rocks free from quartz.

(8) The slaking property of rock powders is dependent in the case of siliceous igneous and metamorphic rocks chiefly on the physical character of the primary mineral components, whereas in basic igneous rocks and sandstones it is caused to a large degree by colloidal products of rock decomposition.

ADDITIONAL COPIES

OF THIS PUBLICATION MAY BE PROCURED FROM

THE SUPERINTENDENT OF DOCUMENTS GOTERNMENT PRINTING OFFICE WASHINGTON, D. C.

AT

10 CENTS PER COPY 